\title{
Progress in Photosynthesis Research
}

\section{Volume 1}

Proceedings of the VIIth International Congress on Photosynthesis, Providence, Rhode Island, USA, August 10-15, $198 \bar{\sigma}$

edited by

\section{J. BIGGINS}

Division of Biology and Medicine, Brown University

Providence, RI 02912, USA 


\section{Distributors}

for the United States and Canada: Kluwer Academic Publishers, P.O. Box 358, Accord Station, Hingham, MA 02018-0358, USA

for the UK and Ireland: Kluwer Academic Publishers, MTP Press Limited, Falcon House, Queen Square, Lancaster LA1 1RN, UK

for all other countries: Kluwer Academic Publishers Group, Distribution Center, P.O. Box 322, 3300 AH Dordrecht, The Netherlands

ISBN 90-247-3450-9 (vol. I)

ISBN 90-247-3451-7 (vol. II)

ISBN 90-247-3452-5 (vol. III)

ISBN 90-247-3453-3 (vol. IV)

ISBN 90-247-3449-5 (set)

\section{Copyright}

(C) 1987 by Martinus Nijhoff Publishers, Dordrecht.

All rights reserved. No part of this publication may be reproduced, stored in a retrieval system, or transmitted in any form or by any means, mechanical, photocopying, recording, or otherwise, without the prior written permission of the publishers, Martinus Nijhoff Publishers, P.O. Box 163, 3300 AD Dordrecht, The Netherlands. 


\section{GENERAL CONTENTS}

\section{Volume I}

1. Excitation Energy Transfer

2. Primary Electron Transfer Reactions 151

3. Chlorophylls and Model Systems 297

4. Structure of Molecular Complexes: Chrystallographic and Physical Studies

5. Oxygen Evolution

Volume II

1. Components and Pigment Protein Complexes a) b) c) d) 1

2. Stoichiometry of Photosystem I and Photosystem II 233

3. Lateral Heterogeneity and Stacking 269

4. Localization of Membrane Components 293

5. Effects of Environmental Changes and Growth Conditions 339

6. Quinone Acceptors 387

7. Cytochromes (b-f) Complex 441

8. Lateral Electron Transport, Connectivity Between 501

9. Plastocyanin 521

10. PSI-cyclic Electron Transport 537

11. Inhibition and Environmental Effects 553

12. General Aspects 613

13. Higher Plants 669

14. Organisms Containing Phycobilins 757

15. Membrane Protein Kinases 797 
Volume III

1. Proton ATP-ase 1

2. Electrochemical Proton Gradients and ATP Synthesis 127

3. Light-dark Regulation of Carbon Metabolism 233

4. Metabolite Regulation of Carbon Metabolism 273

5. Ribulose 1,5 Bisphosphate Carboxylase Oxygenase 371

6. Other Chloroplast Enzymes 435

7. Metabolism of C4 and CAM Plants $5(0) 3$

8. Integration of Carbon and Nitrogen Metabolism 535

9. Photorespiration 549

10. Carbon partitioning 675

11. Herbicide Action 763

Volume IV

1. Photoinhibition 1

2. Temperature 99

3. Water Potentials 147

4. Salinity and Nutrient Deficiency 18.5

$\begin{array}{ll}\text { 5. Regulation of Gas Exchange } & 209\end{array}$

6. Mechanisms of $\mathrm{CO}_{2}$ Concentration 289

7. Crop Productivity 361

8. Biosynthesis of Photosynthetic Pigments 423

9. Photoregulation of Chloroplast Development 511

10. Chloroplast Molecular Genetics $\quad 617$

11. Photosynthetic Bacteria 691

$\begin{array}{ll}\text { 12. Gyanobacteria } & 749\end{array}$ 
CONTENTS TO VOLUME I

General Contents $\quad$ V

Contents Volume I $\quad$ VII

$\begin{array}{lll}\text { Preface } & \text { XXI }\end{array}$

$\begin{array}{ll}\text { Acknowledgments } & \text { XXIII }\end{array}$

Local Organizing Committe XXV

1. Excitation Energy Transfer

Picosecond Absorption and Fluorescence Spectroscopy of Energy

Transfer and Trapping in Photosynthetic Bacteria

R. van Grondelle

Excitation Energy Transport in the Antenna Systems of Purple

Bacteria, Studied by Low-intensity Picosecond Absorption

Spectroscopy

V. Sundström, R. van Grondelle, H. Bergström, E. Åkesson,

T. Gillbro

The Organization of the Light Harvesting Antenna of Purple Bacteria

M. Vos. R.J. van Dorssen, R. van Grondelle, C.N. Hunter.

J. Amesz, L.N.M. Duysens

Photochemical and Non-photochemical Holeburning Studies of

Energy and Electron Transfer in Photosynthetic Reaction Centers and Model Systems

Steven G. Boxer. Thomas R. Middendorf, David J. Lockhart.

David S. Gottfried

The Temperature Dependence of Electron Back-transfer from the

Primary Radical Pair of Bacterial Photosynthesis

David E. Budil, Stephen V. Kolaczkowski, James R. Norris

Supramolecular Organisation of Light-harvesting Pigment-protein

Complexes of Rhodobacter Sphaeroides Studied by Excitation Energy

Transfer and Singlet-singlet Annihilation at Low Temperature in

Phospholipid-enriched Membranes

Willem H.J. Westerhuis, Marcel Vos, Rob J. van Dorssen,

Rienk van Grondelle, Jan Amesz, Robert A. Niederman 
Correlation between the Efficiency of Energy Transfer and the

Polyene Chain Structure of Carotenoids in Purple Photosynthetic

Bacteria

H. Hayashi. K. Iwata. T. Noguchi, M. Tasumi

Triplet Energy Transfer between Photosynthetic Pigments: An ESR

Study of B800-850 Light-harvesting Complexes and Synthetic

Carotenoporhyrin Molecules

Harry A. Frank, Barry W. Chadwick. Chaoying Zhang, Jung Jin Oh

Picosecond Excitation Energy Transfer between Different Light-

harvesting Complexes and Reaction Centres in Purple Bacteria

V.I. Godik, A. Freiberg. K. Timpmann, A.Yu. Borisov,

K.K. Rebane

Spectral Dependence of the Fluorescence Lifetime of Rhodospirillum Rubrum. Evidence for Inhomogeneity of B880 Absorption Band

A. Freiberg. V.I. Godik. K. Timpmann

Protein Phosphorylation: A Mechanism for Control of Excitation

Energy Distribution in Purple Photosynthetic Bacteria

Nigel G. Holmes, John F. Allen

A Model for the Functional Antenna Organization and Energy

Distribution in the Photosynthetic Apparatus of Higher Plants and

Green Algae

Alfred R. Holzwarth

Picosecond Transient Absorbance Spectra and Fluorescence Decay

Kinetics in Photosystem II Particles

A.R. Holzwarth, H. Brock, G.H. Schatz

Picosecond Time Resolved Chlorophyll Fluorescence Spectra from

Pea Chloroplast Thylakoids

G.H. Schatz, A.R. Holzwarth

Picosecond Fluorescence Spectra of Synchronous Cultures of the

Green Alga Scenedesmus Obliquus

E. Bittersmann. H. Senger. A.R. Holzwarth

Measurements and Kinetic Modeling of Picosecond Time-resolved

Fluorescence from Photosystem I and Chloroplasts

Bruce P. Wittmershaus

Time-resolved Fluorescence Decay Kinetics in Photosystem I.

Experimental Estimates of Charge Separation and

Energy Transfer Rates

T.G. Owens, S.P. Webb. D.D. Eads. R.S. Alberte. L. Mets,

G.R. Fleming

Spectral Properties of Photosystem I Fluorescence at Low

Temperatures

J. Wachtveitl, H. Krause 
Analysis of Pigment System I Chl a Fluoresence at Room

Temperature by the Steady State Spectrum and the Time Resolvedspectrum in Picosecond Time Range

Mamoru Mimuro, Iwao Yamazaki, Naoto Tamai. Tomoko Yamazaki, Yoshihiko Fujita

Spectral Shifts in Picosecond Transient Absorption Spectra Due to Stimulated Emission from Chlorophyll in vitro and

in Protein Complexes

D.R. Klug, B.L. Gore, L.B. Giorgi, G. Porter

Fast Fluorescence and Absorption Measurements of Photosystem 1 from a Cyanobacterium

E. Hilary Evans, Raymond Sparrow, Robert G. Brown,

David Shaw. John Barr. Martin Smith and William Toner

Anomalous Fluorescence Induction on Subnanosecond Time Scales and Exciton-exciton Annihilations in PSII

A. Dobek, J. Deprez, N.E. Geacintov, J. Breton

Laser Flash-induced Non-sigmoidal Fluorescence Induction Curves in Chloroplasts

Nicholas E, Geacintov. Jacques Breton. Lee France, Jean Deprez. Andrzej Dobek

Is Variable Fluorescence Due to Charge Recombination?

1. Moya, M. Hodges, J-M. Briantais

Time Resolved Chlorophyll Fluorescence Studies of Photosynthetic Pigment Protein Complexes: Characterisation of

Five Kinetic Components

M. Hodges, I. Moya, J-M. Briantais, R. Remy

Multivariate Analysis of Photosystem II Chlorophyll Fluorescence Quenching by Quinones

K.K. Karukstis, S.C. Boegeman, S.M. Gruber, C.R. Monell,

J.A. Fruetel, M.H. Terris

Energy Transfer in Chlorophyll Antennac of Isolated

PSII Particles

Tomas Gillbro, Åke Sandström. Villy Sundström, Michael Spangfort, Bertil Andersson, Göran Lagenfelt

Polarized Spectra of PS2 Particles in PVA Films

D. Frackowiak, W. Hendrich, M. Romanowski, A. Szczepaniak,

R.M. Leblanc

The Dependence of the Energy Transfer Kinetics of the Higher Plant

Light Harvesting Chlorophyll-protein Complex on Chlorophyll/

Detergent Resolubilisation Ratios

J.P. Ide, D.R. Klug, B. Crystall, B.L. Gore, L.B. Giorgi,

W. Kuhlbrandt, J. Barber, G. Porter 
Characterization of the Fluorescence Decays of the Chlorophyll a/b Protein

D.D. Eads, S.P. Webb, T.G. Owens, L. Mets. R.S. Alberte,

G.R. Fleming

Fluorescence Decay and Depolarization Kinetics Calculated Using

Förster Inductive Resonance and the Molecular Coordinates for

C-phycocyanin

Kenneth Sauer, Hugo Scheer

Photochemistry and Photophysics of C-phycocyanin

Hugo Scheer

\section{Primary Electron Transfer Reactions}

Primary Reactions of Photosynthesis: Discussion of Current Issues

Paul Mathis

Selective Reduction and Modification of Bacteriochlorophylls and Bacteriopheophytins in Reaction Centers from

Rhodopseudomonas Viridis

V.A. Shuvalov, A.Ya. Shkuropatov, M.A. Ismailov

Spectroscopic and Primary Photochemical Properties of Modified Rhodopseudomonas Sphaeroides Reaction Centers

Dewey Holten, Christine Kirmaier, Leanna Levine

Fourier Transform Infrared (FTIR) Spectroscopic Investigations of the Primary Reactions in Purple Photosynthetic Bacteria

E. Nabedryk, B.A. Tavitian, W: Mäntele, W. Kreutz, J. Breton

Picosecond Characterization of Primary Events in

Rhodopseudomonas Viridis Whole Cells by Transmembrane

Potential Measurements

J. Deprez, H.-W. Trissl, J. Breton

Excitation of Antenna Pigments and Electron Transfer upon

Picosecond Flash Illumination of Membranes of

Chloroflexus Aurantiacus

185

A.M. Nuijs, H. Vasmel, L.N.M. Duysens, J. Amesz

Electron Transport in Heliobacterium Chlorum

H.W.J. Smit, J. Amesz, M.F.R. van der Hoeven, L.N.M. Duysens

A Possible Mechanism for Electron Transfer in the Diquinone Acceptor Complex of Photosynthetic Reaction Centers

S.K. Buchanan, K. Ferris, G.C. Dismukes

Triplet-minus-singlet Absorption Difference Spectra of Some

Bacterial Photosynthetic Reaction Centers with and without Carotenoids Recorded by Magneto-optical Difference Spectroscopy (MODS) at 290 and $20 \mathrm{~K}$ 
An E.P.R. Signal Arising from $\mathrm{Q}_{\mathrm{B}}{ }^{-} \mathrm{Fe}$ in Chromatium Vinosum

Strain D

P. Heathcote, A.W. Rutherford

Photochemical Reduction of either of the Two Bacteriopheophytins in

Bacterial Photosynthetic Reaction Centers

Sandra Florin, David M. Tiede

Reconstitution of Reaction Centers in Planar Bilayer Lipid

Membranes (BLM)

H. Ti Tien

$3\left(\mathrm{P}^{-} \mathrm{I}^{-}\right)$Lifetime as Measured by $\mathrm{B}_{1}$ Field Dependent

RYDMR Triplet Yield

Stephen Kolaczkowski, David Budil. James R. Norris

Electron Transfer in Reaction Center Protein from $R$. Sphaeroides:

Generation of a Spin Polarized Bacterio-chlorophyll Dimer EPR

Signal Whose Formation is Modulated by the Electron Transfer Rate from Bacteriopheophytin to $\mathrm{Q}_{\text {A }}$

M.R. Gunner, D.E. Robertson, R.L. LoBrutto. A.C. McLaughlin, P.L. Dutton

Electric Field Dependence of Electron Transfer in Photosynthetic

Reaction Centers from Rhodopseudomonas Sphaeroides

G.A. Alegria, P.L. Dutton

Hydrocarbon Tail Structure and its Effect on the Affinity and Kinetic Performance of Quinones at the $\mathrm{Q}_{A}$ Site in Reaction Centers of

Rhodobacter Sphaeroides R26

K. Warncke, M.R. Gunner, B.S. Braun, C.-A. Yu, P.L. Dutton

Excited States and Primary Photochemical Reactions in

Photosystem I

A.M. Nuijs, V.A. Shuvalov, H.W.J. Smit, H.J. van Gorkom,

L.N.M. Duysens

Characterization of the Electron Acceptor $A_{1}$ in Photosystem I by

Flash-absorption Spectroscopy at Low Temperature: Evidence that

$A_{1}$ is Vitamin $K_{1}$

K. Brettel, P. Setif, P. Mathis

EPR Evidence that the Photosystem I Acceptor $A_{1}$ is a

Quinone Molecule

M.C. Thurnauer, P. Gast, J. Petersen, D. Stehlik

Investigation of the Chemical Nature of Electron Acceptor $A_{1}$ in

Photosystem I of Higher Plants

R.W. Mansfield, J.H.A. Nugent, M.C.W. Evans

Evidence for the Existence of Electron Acceptors $A_{11}$ and $A_{1}$ in

Cyanobacterial Photosystem 1

N.S. Smith, R.W. Mansfield. J.H.A. Nugent, M.C.W. Evans 
Iron X-ray Absorption Spectra of Acceptors in PS I

Ann E. McDermott, Vittal K. Yachandra, R.D. Guiles,

R. David Britt, S.L. Dexheimer, Kenneth Sauer, Melvin P. Klein

Photosystem I Charge Separation in the Absence of Centers A \& B:

Biochemical Characterization of the Stabilized P700 A2(X) Reaction

Center

John H. Golbeck, Kevin G. Parrett. Leslie L. Root

Picosecond Transient Absorption Spectroscopy of Photosystem 1

Reaction Centres from Higher Plants

L.B. Giorgi, B.L. Gore, D.R. Klug, J.P. Ide, J. Barber,

G. Porter

Light-induced Fourier Transform Infrared (FTIR) Spectroscopic

Investigations of Primary Reactions in Photosystem I and

Photosystem II

B.A. Tavitian, E. Nabedryk, W. Mäntele, J. Breton

Chlorophyll Organization in Photosystem-l Reaction-center of

Spinach Chloroplasts

Isamu Ikegami, Shigeru Itoh

Bound Quinones in the Reaction Centres of Bacteria and Plants M.C.W. Evans

How Close is the Analogy between the Reaction Centre of PSII and that of Purple Bacteria? 2. The Electron Acceptor Side

A.W. Rutherford

Depletion and Reconstitution of the Quinone at the $Q_{13}$ Site in

Photosystem II: A Thermoluminescence Study

T. Wydrzynski, Y. Inoue

Chemically-induced Dynamic Electron Polarization in Photosystem 2

Reaction Centers

Joseph T. Warden, Nathan M. Lacoff, Károly Csatorday

The Mechanism of Fatty Acid Inhibition in Photosystem 2

Károly Csatorday, Claire Walczak, Joseph T. Warden

\section{Chlorophylls and Model Systems}

In vivo Spectral Peaks Related to New Chemical Species of

Chlorophylls: 4-Vinyl-4-Desethyl

Maarib B. Bazzaz

Chlorophyll $a^{\prime}$ in Photosynthetic Apparatus: Reinvestigation

Tadashi Watanabe, Masami Kobayashi, Masataka Nakazato,

Isamu Ikegami, Tetsuo Hiyama 
Are Chlorinated Chlorophylls Components of Photosystem I

Reaction Centers?

J. Fajer, E. Fujita, H.A. Frank. B. Chadwick. D. Simpson,

K.M. Smith

Environmental Effects on the Properties of Chlorophylls in vivo

Theoretical Models

L.K. Hanson, M.A. Thompson, J. Fajer

Effects of Structure and Geometry of Pigment-Protein Complexes on

Experimental Quantities in Primary Processes of Photosynthesis

K. Vacek. M. Ambroz, O. Bilek, J. Hala, V. Kapsa, P. Pancoska,

I. Pelant, L. Skala, L. Souckova

Infrared Study of Solid Chlorophyll a Absorbing Near $700 \mathrm{~nm}$ at

Room Temperature

Camille Chapados

Borohydride Reduction of Bacteriochlorophyll $a$ in the Light

Harvesting Protein of Rhodospirillum Rubrum

Patricia M. Callahan, Therese M. Cotton. Paul A. Loach

Fourier-transform Infrared (FTIR) Spectroelectrochemistry of

Bacteriochlorophylls

W. Mäntele, A. Wollenweber, E. Nabedryk, J. Breton, F. Rashwan.

J. Heinze, W. Kreutz

Solvent Effects on the Transfer Kinetics of

Bacteriochlorophyll Oxidation

Therese M. Cotton. Randall L. Heald

$\mathrm{X}$ - and Y-polarized Absorptions of Chlorophyll $a$ and Pheophytin a

Oriented in a Lamellar Phase of Glycerylmonooctanoate/water

M. Fragata, T. Kurucsev, B. Nordén

The Bacteriochlorophyll $c$ Dimer in Carbon Tetrachloride

J.M. Olson. G.H. van Brakel, P.D. Gerola. J.P. Pedersen

Superoxide Photogeneration by Chlorophyll $a$ in Water/Acetone

Solutions. Electron Spin Resonance Studies of Radical Intermediates

in Chlorophyll a Photoreactions in vitro

Jun-Lin You, Karen S. Butcher. Angela Agostiano, Francis K. Fong

Resonant Energy Transfer between Bulk Chlorophyll $a$ and

Chlorophyll $a$ Dihydrate Dimers in Water/Acetone Mixtures.

A Model of Sensitized Excitation in Plant Photosynthesis

Angela Agostiano, Karen A. Butcher, Michael S. Showell,

Jun-Lin You, Albert J. Goth. Michael S. Showell

4. Structure of Molecular Complexes: Crystallographic and Physical Studies

The Structural Organization of Photosynthetic Reaction Centers

Hartmut Michel, Johann Deisenhofer 
Relating Structure to Function in Bacterial Photoreaction Centers

J.R. Norris, D.E. Budil. D.M. Tiede, J. Tang. S.V. Kolaczkowski,

C.H. Chang, M. Schiffer

Crystallographic Studies of the Photosynthetic Reaction Center from

R. Sphaeroides

C.-H. Chang, D. Tiede, J. Tang, J. Norris, M. Schiffer

Structure Analysis of the Reaction Center from Rhodopseudomonas Sphaeroides: Electron Density Map at 3.5Å Resolution

J.P. Allen. G. Feher, T.O. Yeates, D.C. Rees

Evidence of the Primary Charge Separation in the $D_{1} D_{2}$ Complex of Photosystem II from Spinach: EPR of the Triplet State

M.Y. Okamura, K. Satoh, R.A. Isaacson. G. Feher

Crystallization and Spectroscopic Investigations of the Pigmentprotein Complexes of Rhodopseudomonas Palustris

T. Wacker, K. Steck, A. Becker, G. Drews, N. Gad'on, W. Kreutz, W. Mäntele, W. Welte

Spectroscopy, Structure and Dynamics in the Reaction Center of Rhodopseudomonas Viridis

J. Breton, J. Deprez. B. Tavitian. E. Nabedryk

Interspecific Structural Variations of the Primary Donor in

Bacterial Reaction Centers

Qing Zhou, Bruno Robert, Marc Lutz

Linear-Dichroic Absorbance Detected Magnetic Resonance

(LD-ADMR) Spectroscopy of the Photosynthetic Reaction Center of Rhodopseudomonas Viridis. Spectral Analysis by Exciton Theory

E.J. Lous, A.J. Hoff

Optical Properties of the Reaction Center of Chloroflexus Aurantiacus at Low Temperature. Analysis by Exciton Theory

H. Vasmel, R.F. Meiburg, J. Amesz, A.J. Hoff

The Photochemical Reaction Center of Chloroflexus Aurantiacus:

Isolation and Protein Chemistry of the Purified Complex

Judith A. Shiozawa, Friedrich Lottspeich, Reiner Feick

Structures of Antenna Complexes and Reaction Centers from

Bacteriochlorophyll b-containing Bacteria:

Resonance Raman Studies

Bruno Robert, Robert Steiner, Qing Zhou. Hugo Scheer,

Marc Lutz

Strong Orientational Ordering of the Near-infrared Transition Moment Vectors of Light-harvesting Antenna Bacterioviridin in Chromatophores of the Green Photosynthetic Bacterium Chlorobium Limicola. Strain c

Z.G. Fetisova, S.G. Kharchenko, I.A. Abdourakchmanov 
Light Absorption and Fluorescence of $\mathrm{BChl}(\mathrm{c}$ in Chlorosomes from Chloroflexus Aurantiacus and in an in vitro Model

Daniel C. Brune, Robert E. Blankenship

Serrs as a Probe for Pigments Located near the Surfaces of Bacterial Photosynthetic Membranes

Rafael Picorel, Randall E. Holt, Therese M. Cotton,

Michael Seibert

Optical Excited Triplet States in Antenna Complexes of the Photosynthetic Bacterium Rhodopseudomonas Capsulata Ala ${ }^{+}$ Detected bij Magnetic Resonance in Zero-field

A. Angerhofer, J.U. von Schütz, H.C. Wolf

Singlet Energy Transfer in Photosynthetic Bacteria: Absorption and Fluorescence Excitation of B800-850 Complexes

Barry W. Chadwick, Harry A. Frank. Chaoying Zhang.

Shahriar S. Taremi, Richard J. Cogdell

Properties of the Core Complex of Photosystem II

J.J. Plijter, R.J. van Dorssen, J.P. Dekker, F.T.M. Zonneveld,

H.J. van Gorkom. J. Amesz

Pigment Arrangement in Photosystem II

R.J. van Dorssen, J.J. Plijter, A. den Ouden, J. Amesz,

H.J. van Gorkom

Three-dimensional Crystals of the Light-harvesting Chlorophyll

a/b Protein Complex from Pea Thylakoids

W. Kuehlbrandt

Interpretation of Transient Linear Dichroism Spectra of

LHC Particles

Robert S. Knox, Su Lin

Resonance Raman Spectroscopy of Chlorophylls and the

Light-harvesting Chlorophyll $\mathrm{a} / \mathrm{b}$ Protein

H.N. Fonda, G.T. Babcock

\section{Oxygen Evolution}

Oxygen-evolving Complex of Photosystem II in Higher Plants

Norio Murata, Mitsue Miyao

Kinetics and Structure on the High Potential Side of

Photosystem II

G.T. Babcock, T.K. Chandrashekar, D.F. Ghanotakis,

C.W. Hoganson, P.J. O`Malley, I.D. Rodriguez, C.F. Yocum

Endor Characterization of $\mathrm{H}_{2} \mathrm{O} / \mathrm{D}_{2} \mathrm{O}$ Exchange in the $\mathrm{D}^{+} \mathrm{Z}^{+}$Radical in Photosynthesis

I.D. Rodriguez, T.K. Chandrashekar, G.T. Babcock 
Endor Characterization of the $\mathrm{Z}^{+} / \mathrm{D}^{+}$Species in Photosystem II and Relevant Model Compounds

T.K. Chandrashekar, P.J. O`Malley. I.D. Rodriguez, G.T. Babcock

Time-resolved ESR Spectrum of $Z^{-}$in Oxygen-evolving

Photosystem II Membranes

C.W. Hoganson. Y. Demetriou. G.T. Babcock

Spatial Relationship between the Intramembrane Components ( $D^{+}$.

$\mathrm{Z}^{+}$) which Give Rise to Signal II and the Membrane Peripheral

Proteins Working in Photosystem II Oxygen Evolution Studied by the

Effect of Spin-relaxing Reagent Dysprosium

483

Shigeru Itoh, Yasuhiro Isogai, Xiao-Song Tang, Kimiyuki Satoh

The Effects of Chemical Oxidants on the Electron Transport

Components of Photosystem II and the Water-oxidizing Complex

J. Tso. D. Hunziker. G.C. Dismukes

On the Mechanism of Photosynthetic Water Oxidation

Gary W. Brudvig. Julio C. de Paula

Coordination of Ammonia, but not Larger Amines, to the

Manganese Site of the $\mathrm{O}$-evolving Center in the $\mathrm{S}_{2}$ State

Warren F. Beck. Gary W. Brudvig

EPR Studies of the Oxygen-evolving system. The Interaction

with Amines

Lars-Erik Andreasson, Örjan Hansson

Cooperative Binding of Hydroxylamine and Hydrazine to the

Water-oxidizing Complex

Verena Förster, Wolfgang Junge

Reaction Mechanisms of $\mathrm{H}_{2} \mathrm{O}$ Substrate Analogues at the PS II-donor

Side in Thylakoids and PS III-particles

B. Hanssum, G. Renger

Proton Release by Photosynthetic Water Oxidation

Ralf Diedrich-Glaubitz, Manfred Völker, Gernot Renger.

Peter Gräber

On the Cleavage of Water

Pattern of Charges and Protons. States of Water and Manganese.

Routes and Rate of Intermediates

H.T. Witt. Ö. Saygin. K. Brettel, E. Schlodder

Absorption Changes with Periodicity Four. Associated with

Photosynthetic Oxygen Evolution

Jan P. Dekker, Johan J. Plijter, Hans J. van Gorkom

State of Manganese During Water Splitting

Ö. Saygin, H.T. Witt

New Results about the Molecular Mechanism of

Photosynthetic Water Oxidation

G. Renger, B. Hanssum, W. Weiss 
The Modification of the Donor Side Reaction Pattern in

PS II Membrane Fragments by Trypsin and $\mathrm{CaCl}_{2}$

M. Völker. H.J. Eckert, G. Renger

Studies on Water Oxidation by Mass Spectrometry in the

Filamentous Cyanobacterium Oscillatoria Chalybea

Klaus P. Bader, Pierre Thibault, Georg H. Schmid

Flash-induced Enhancements in the 'H-relaxation Rate of

Photosystem II Particles

A.N. Srinivasan, R.R. Sharp

The State of Manganese in the Photosynthetic Apparatus:

An X-ray Absorption Spectroscopy Study

Vittal K. Yachandra. R.D. Guiles, Ann McDermott, James Cole.

R. David Britt, S.L. Dexheimer, Kenneth Sauer, Melvin P. Klein

Structural Features of the Manganese Cluster in Different States of the Oxygen Evolving Complex of Photosystem II:

An X-ray Absorption Spectroscopy Study

R.D. Guiles, Vittal K. Yachandra, Ann E. McDermott.

R. David Britt, S.L. Dexheimer. Kenneth Sauer, Melvin P. Klein

Characterization of the $\mathrm{MN}$-containing $\mathrm{O}$, Evolving Complex from

the Cyanobacterium Synechococcus Using EPR and

X-ray Absorption Spectroscopy

565

Ann McDermott, Vittal K. Yachandra. R.D. Guiles, R. David Britt.

S.L. Dexheimer, Kenneth Sauer, Melvin P. Klein

The Flash Number Dependence of EPR Signal II Decay As a Probe for Charge Accumulation in Photosystem II

James Cole, Kenneth Sauer

Electron Spin Echo Studies of PSII Membranes

R. David Britt. Kenneth Sauer. Melvin P. Klein

EPR Studies at 9 and $34 \mathrm{GHz}$ of the Multiline and

$g=4.1$ S, Signals

Roland Áasa, Örjan Hansson. Tore Vänngärd

Structural and Functional Aspects of Electron Transfer in

Photosystem 2 of Oxygen-evolving Organisms

V.V. Klimov, I.B. Ganago, S.I. Allakhverdiev. M.A. Shafiev,

G.M. Ananyev

The Study of Effects on Strongly-bound Manganese of

Oxygen Evolving Complex in Wheat Chloroplasts by EPR

Sun Qi. Luo Chang-Mei, Zhang Li-Li. Fang Zhao-Xi. Mei Zhen-An

Evidence for the Role of Functional Manganese in

Hydrogen-peroxide-stimulated Oxygen Production of the First Flash

in $\mathrm{CACL}_{2}$-washed Photosystem II Membranes

Steven P. Berg. Michael Seibert 


\section{XVIII}

Interaction between Manganese and the 33-kilodalton Protein in

Spinach PS II

Yasusi Yamamoto

Manganese and Calcium Binding Properties of the Extrinsic

$33 \mathrm{kDa}$ Protein and of Photosystem II Membranes

D. Hunziker, D.A. Abramowicz, R. Damoder. G.C. Dismukes

The $33 \mathrm{kDa}$ Extrinsic Polypeptide of Photosystem II is not a Ligand to Manganese in the $\mathrm{O}_{2}$ Evolving Complex

Anne-Frances Miller, Julio C. de Paula, Gary W. Brudvig

Effect of Release of the 17 and $23 \mathrm{kDa}$ Polypeptides of

Photosystem II on Cytochrome $b_{5 ; 1}$

Julio C. de Paula, Brian W. Wu, Gary W. Brudvig

Cytochrome $b_{55 y}$ Plays a Structural Role in the Oxygen Evolving

Complex of Photosystem II

Lynmarie K. Thompson. Julian M. Sturtevant, Gary W. Brudvig

Effect of the 33-kDa Protein on the S-state Transition in the

Oxygen-evolving Complex

M. Miyao, N. Murata, B. Maison-Peteri, A. Boussac, A.-L. Etienne,

J. Lavorel

PSII Ca Abundance and Interaction of the 17,24 kD Proteins with the

$\mathrm{C1}^{-} / \mathrm{Ca}^{2+}$ Essential for Oxygen Evolution

Kirk Cammarata, George Cheniae

Photoactivation of the Water Oxidizing Complex by

Photosystem 2 Membranes

N. Tamura, G. Cheniae

Numbers of Calcium Ions Associated with Oxygen Evolving

Photosystem II Preparations with Different Affinities

Sakae Katoh. Kazuhiko Satoh. Takashi Ohno, Jian-Ren Chen,

Yasuhiro Kasino

Involvement of $\mathrm{Ca}^{2+}$ and the $33 \mathrm{kD}$ Polypeptide in $\mathrm{Cl}^{-}$Binding to the Oxygen Evolving Complex of Photosystem II

W.J. Coleman. Govindjee, H.S. Gutowsky

Inhibition at the $\mathrm{CA}^{2+}$ Sensitive Site of the Oxygen Evolving Center

by Ruthenium Red

Sylvie Lemieux, Robert Carpentier

Thermoluminescence Studies of the Abnormal S-states Formed in $\mathrm{Cl}^{-}$-depleted or $33 \mathrm{kDa}$ Extrinsic Protein-depleted PSII

Yorinao Inoue

Temperature Dependence of the S-state Transition in a Thermophilic Cyano-bacterium Measured by Thermoluminescence Hiroyuki Koike, Yorinao Inoue 
Depletion of $\mathrm{Cl}^{-}$or $33 \mathrm{kDa}$ Extrinsic Protein Modifies the Stability of $\mathrm{S}_{2} \mathrm{Q}_{\bar{A}}^{-}$and $\mathrm{S}_{2} \mathrm{Q}_{\mathrm{B}}^{-}$Charge Separation States in PS II

Imre Vass, Taka-aki Ono, Peter H. Homann, Hermann Gleiter, Yorinao Inoue

Abnormal $\mathrm{S}_{2}$ State Formed in Chloride Depleted Photosystem II as Revealed by Manganese EPR Multiline Signal

T. Ono, J.L. Zimmermann, Y. Inoue, A.W. Rutherford

$\mathrm{Cl}^{-}$Dependent Binding of the Extrinsic $23 \mathrm{kDa}$ Polypeptide at the

Water Oxidizing Site of Chloroplast Photosystem II

Peter H. Homann

Effects of Chloride on Paramagnetic Coupling of Manganese in

Calcium Chloride-washed Photosystem II Preparations

Gopinath Mavankal, Douglas C. McCain, Terry M. Bricker

Accessibility for, and Production of $\mathrm{H}_{2} \mathrm{O}_{2}$ Related to PS-II

Wolfgang P. Schröder, Hans-Erik Åkerlund

Reversible Inhibition of Photosystem Two Electron Transfer

Reactions and Specific Removal of the Extrinsic 23 kDa Polypeptide

by Alkaline $\mathrm{pH}$

David J. Chapman, James Barber

$\mathrm{O}_{2}$ Flash Yield Sequences of Photosystem II Membranes-Sequential

Extraction of the Extrinsic Proteins

Michael Seibert, Brigitta Maison-Peteri, Jean Lavorel

Comparative Study of Period 4 Oscillations of the Oxygen and

Fluorescence Yield Induced by a Flash Series in Inside out Thylakoids

M.J. Delrieu, F. Rosengard

Purification of an Oxygen Evolving Photosystem II Reaction Center

Core Preparation

D.F. Ghanotakis, D.M. Demetriou, C.F. Yocum

Selective Depletion of Water-soluble Polypeptides Associated with Photosystem II

Charlene M. Waggoner, Charles F. Yocum

Binding of the 17 and $23 \mathrm{kDa}$ Water-soluble Polypeptides to a Highlyresolved PSII Reaction Center Complex

Stewart Merritt, Patrik Ernfors, Demetrios Ghanotakis,

Charles Yocum

A Manganese Containing Protein Complex Isolated from

Photosystem II Preparations of Spinach

Neil R. Bowlby, Wayne D. Frasch

Purification and Proteinchemical Characterization of the Extrinsic

Membrane Proteins in the Water Splitting System of Spinach

Joachim Vater, Johann Salnikow, Ricci Zepmeusel, Christer Jansson 
Partial Amino Acid Sequences of the Proteins of Pea and Spinach Photosystem II Complex

N. Murata, H. Kajiura, Y. Fujimura, M. Miyao, T. Murata,

A. Watanabe, K. Shinozaki

Proline-rich Structure at Amino-terminal Region of the 18-kDa

Protein of Photosynthetic Oxygen-evolving Complex

Tomohiko Kuwabara, Teruyo Murata, Mitsue Miyao, Norio Murata

Topographical Studies on Subunit Polypeptides of Oxygen-evolving Photosystem II Preparations by Reversible Crosslinking: Functions of Two Chlorophyll-carrying Subunits

Isao Enami, Takeshi Miyaoka, Sahoko Igarashi, Kazuhiko Satoh,

Sakae Katoh

Tenacious Association of the $33 \mathrm{kDa}$ Extrinsic Polypeptide

(Water Splitting) with PS II Particles

Edith L. Camm, Beverley R. Green

Thermodynamic Constraints to Photosynthetic Water Oxidation

Lee Spencer, Donald T. Sawyer, Andrew N. Webber,

Robert L. Heath

Binuclear and Tetranuclear Manganese Complexes: As Models for the Site for Photosynthetic Water Oxidation

J.E. Sheats, B.C. UnniNair, V. Petrouleas, S. Artandi,

R.S. Czernuszewicz, G.C. Dismukes

Models for Manganese Centers in Metalloenzymes

Vincent L. Pecoraro, Dimitris P. Kessissoglou, Xinhua Li,

William M. Butler

Molecular Orbital Study (IV) on the 'Microsurface' Model of

Catalytic Binuclear Manganese Complex in Photosynthetic Water-

splitting and Oxygen-evolving Reaction

Masami Kusunoki

Dynamic Linearity of the Bare Platinum Electrode for Oxygen

Exchange Measurements in Marine Algae

S.I. Swenson, C.P. Meunier, K. Colbow

A Dynamic Model for the Bare Platinum Electrode

C.P. Meunier, S.I. Swenson, K. Colbow 


\section{I.5.740}

\section{REFERENCES}

1 Swenson, S.I., Colbow, K. and Vidaver, W.E. (1986) Plant Physiol. 80, 346-349

2 Kleinbaum, D.G., Kupper, L.L. (1978) in Applied Regression Analysis and other Multivariable Methods (Service to Publishers Inc., ed.), pp. 158162, Duxbury Press, Belmont, California

3 Joliot, P., Hofning, M. and Chabaud, R. (1966) J. Chim. Phys., 63, 1423-1441

4 Hoare, J.P. (1985) J. Electrochem. Soc., 132, 301-305

5 Gille, J-Ch., Decaulne, P. and Pelegrin, M. (1981) in Dynamique de la commande lineaire (Dunod, ed.), 6th ed., pp. 275-284, Bordas, Paris

6 Dekker, J.P., Plijter, J.J., Ouwehand, L. and Van Gorkom, H.J. (1984) Biochim. Biophys. Acta, 767, 176-179

7 Diner, B.A. (1974) in Proceedings of the IIIrd International Congress on Photosynthesis (Avron, M., ed.), Vol. 1, pp. 589-601, Elsevier, Amsterdam

8 Diner, B.A. (1977) Biochim. Biophys. Acta 260, 247-258 
STRUCTURES OF ANTENNA COMPLEXES AND REACTION CENTERS FROM BACTERIOCHLOROPHYLL B-CONTAINING BACTERIA : RESONANCE RAMAN STUDIES

Bruno ROBERT, Robert STEINER*, Qing ZHOU, Hugo SCHEER * and MarC LUTZ

Département de Biologie, CEN Saclay 91191 Gif sur Yvette Cedex France

and *: Botanisches Institut der Universität Munchen, D 8000 Munchen 19, GFR

Resonance Raman (RR) spectroscopy yields detailed information about the structure and ground-state environmental interactions assumed by bacteriochlorophyll a (BChl a) and bacteriophaeophytin a (Bpheo a) within bacterial pigment-protein complexes (1-3). Recent successes in crystallyzing reaction centers (RC) from Rhodopseudomonas viridis renewed interest in $\mathrm{BChl} b-$ and Bpheo b-containing complexes (4). We here report the first $R R$ spectra of isolated BChl $b$ and Bpheo $b$, as well as of BChl bcontaining antenna and reaction centers. Difficulties due to the high photooxydability of those pigments have been overcome by working at $20 \mathrm{k}$ in anoxic conditions, and by selectively avoiding resonance of decay products $(363.8 \mathrm{~nm}$ excitation).

\section{RR SPECTRA OF ISOLATED BCHL B AND BPHEO B}

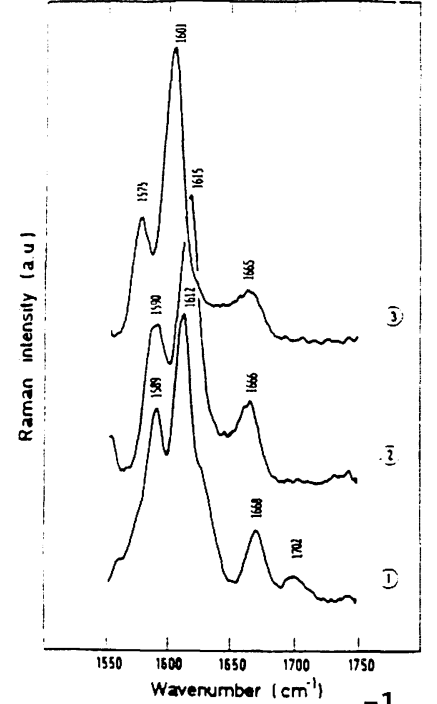

Fig $1: 1550-1750 \mathrm{~cm}^{-1}$ regions

Comparison of $\mathrm{BChl} a$ and $\mathrm{BChl} b$ RR spectra shows that the presence of the ethylidene grouping conjugated to cycle ${ }_{1}$ II induces some large ( $6 \mathrm{~cm}^{-1}$ ) frequency shifts, principally of bands at 697, 952, 1161, 1218, and $1444 \mathrm{~cm}^{-1}$ (BChI a). Except the $1161 \mathrm{~cm}^{-1}$ one, these modes are ${ }_{15}$ eakly sensitive to the ${ }^{14} \mathrm{~N} /{ }^{15} \mathrm{~N}$ substitution and thus should involve motions of the macrocycle periphery (3). $\mathrm{BChl} b$ yields two strong bands at 650 and $1351 \mathrm{~cm}^{-1}$ (Bpheo b : $1347 \mathrm{~cm}^{-1}$ ), which are missing in BChl a spectra. These modes do not appear to predominantly arise from the ethylidene grouping.

Differences observable between RR spectra of $B C h l b$ and of Bpheo $b$ are very similar to those observed for the a derivatives (3). In

1) Bpheo b in methanol

2) BChl b in hexane

3) BChl b in methanol

$(\mathrm{T}=20 \mathrm{~K}$; exc. $\mathrm{wv}: 364 \mathrm{~nm})$ particular, characteristic bands of phaeophytins at $270,777,1106$, 1131 and $1590 \mathrm{~cm}^{-1}$ are present in 


\section{I.4.412}

Bpheo b RR spectra.

Free carbonyl stretching modes at 1678 and $1700 \mathrm{~cm}^{-1}$

(fig

1.3) indicate that the 9-keto carbonyl stretching frequency is not affected by the presence of the additional $\mathrm{C}=\mathrm{C}$ bond conjugated with cycle II, whereas the stffetching mode of the 2-acetyl $C=0$ is upshifted by about $15 \mathrm{~cm}^{-1}$.

Fig 1.2 and 1.3 compare the higher frequency regions of $R R$ spectra of $\mathrm{BChl} b$ in a polar solvent (central Mg 6-coordinated) and self-aggregated in a non polar solvent (central Mg 5-coordinated). This clearly shows that the methine bridge stretching mode of $\mathrm{BChl}$ $\mathrm{b}$ is sensitive to the coordination state of the centraf $\mathrm{Mg}$ of the molecule, being located, as in BChl a, around $1614 \mathrm{~cm}^{-1}$, when 5coordinated, and around $1600 \mathrm{~cm}^{-1}$ when 6-coordinated.

\section{INTERACTION STATES OF BCHU B IN ANTENNA COMPLEXES}

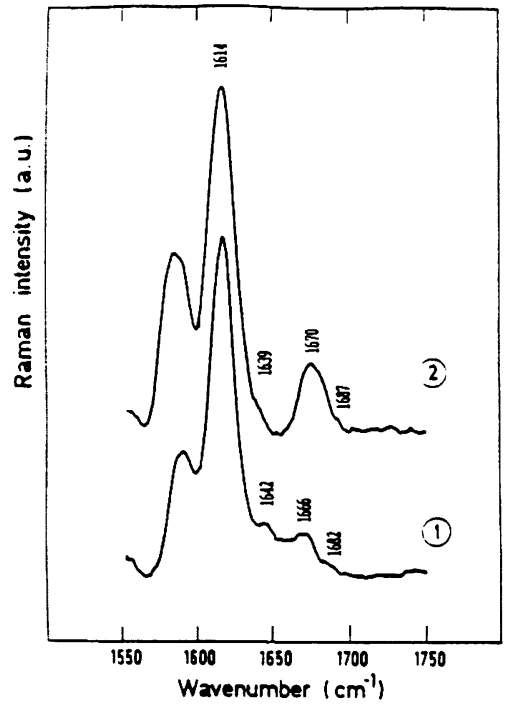

Fig 2 : RR spectra of : 1 : B 800-1020 complexes from Ectothiorhodospira halochloris

2 : Chromatophores from Rhodopseudomonas viridis

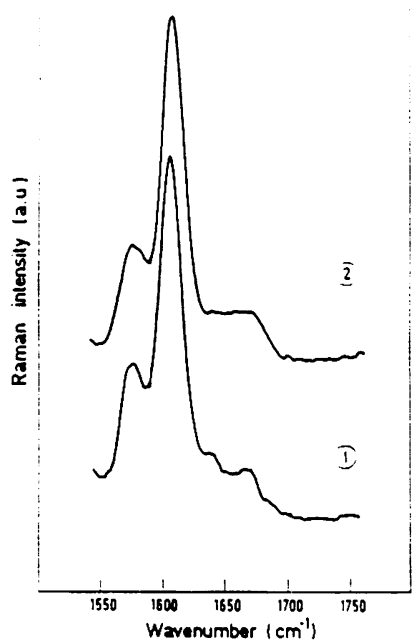

Fig 3 :

1 : cf fig. 2.1

2 : RR spectra of the same complex after $\mathrm{HCl}$ treatment

Fig 2.2 displays the higher frequency region of $R R$ spectra of whole chromatophores of Rps viridis : because of the low $(0.08)$ RC : antenna ratio, these spectra essentially arise from B 1015 antenna complexes alone. Fig 2.1 shows the same frequency range for purified B 800-1020 antenna complexes from Ectothiorhodospira halochloris. In both of these spectra, the frequency of the methine bridge stretching mode, being located around $1613 \mathrm{~cm}^{-1}$, clearly demonstrates that, as BChl a, BChl $b$ is preferentially 5coordinated when bound to protein.

In the carbonyl stretching frequency region, $R R$ spectra of B 1015 complexes from Rps viridis are quite different from those of the supposedly (5) homologous BChl a-containing B 880 complexes 
from Rhodospirillales (1). Indeed, if the number of conjugated $C=0$ vibrators observable in the spectra (three) is consistent with the stoichiometry proposed for these complexes (2 BChl b / copplex), the Irequencies of these vibrators (1639, 1670 and $1687 \mathrm{~cm}^{-1}$ ) are different from those observed in B 880 complexes (1). Indeed, the present spectra show that one acetyl carbonyl of one $-\rho^{\prime}$ the two $\mathrm{BChl} b$ is intermolecularly bound, vibrating at $1639 \mathrm{~cm}^{-1}$, whereas that of the other is free, vibrating at $1670 \mathrm{~cm}^{-1}$. Moreover, the latter Raman band is very likely degenerate, and most probably involves one keto carbonyl, thep intermolecularly bound. The second keto group vibrates at $1687 \mathrm{~cm}^{-1}$ and is only weakly interacting. One thus has to conclude that ground-state molecular interactions assumed by BChl b in B 1015 complexes differ from those assumed by BChl a in B 880 complexes : in the latter, which form a homogeneous class from a structural point of view (1), both of the acetyl carbonyls of the BChl a molecules are intermolecularly bound, and vibrate around $1643 \mathrm{~cm}^{-1}$.

RR spectra of B 800-1020 of halochloris show that at least four unequivalent $\mathrm{BChl} b$ are present in these complexes (table 1 ). This result agrees with the stoichiometry deduced from biochemical data (5 BChl b / complex)(6). Acid treatment of this complex induces a shift of the $1020 \mathrm{~mm}$ transition to $960 \mathrm{~mm}$ (6). This treatment affects the stretching frequencies of no more than two acetyl and two keto carbonyl groups (Fig 3 and Table 1). This confirms the hypothesis according to which (7) two out of the five $\mathrm{BChl} b$ molecules participate to the $1020 \mathrm{~nm}$ absorption band.

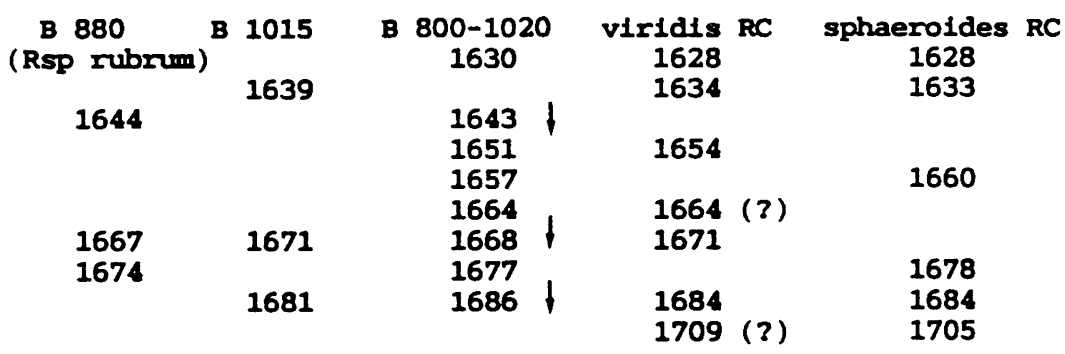

Table 1 : compared frequencies of $\mathrm{BChl}$ b- and BChl a-containing complexes. ( $f$ : intensity variations induced by $\mathrm{HCl}$ treatment)

BCHIL B-CONTAINING REACTION CENTERS

We obtained RR spectra of reaction centers from Rps viridis (fig 4). In the lower and medium frequencies regions of these spectra, the main bands predominantly arise from Bpheo $b$ and $\mathrm{BChl} b$ appears to poorly contribute. However, in the higher frequency region, the low $1590: 1615 \mathrm{~cm}^{-1}$ intensity ratio indicates a strong participation of $\mathrm{BChl} b$. Moreover, the carbonyl stretching frequency region does not contain all of the 4 frequencies that are observed when resonance is with the 535-545 nm transition, hence selectively enhancing Bpheo contributions(8). Such a frequency-dependent balance of BChl / Bpheo contributions is also observed in RR spectra of RCs from Rhb sphaeroides $R 26$ 
excited at $364 \mathrm{~nm}$ (Robert, B. unpublished results).
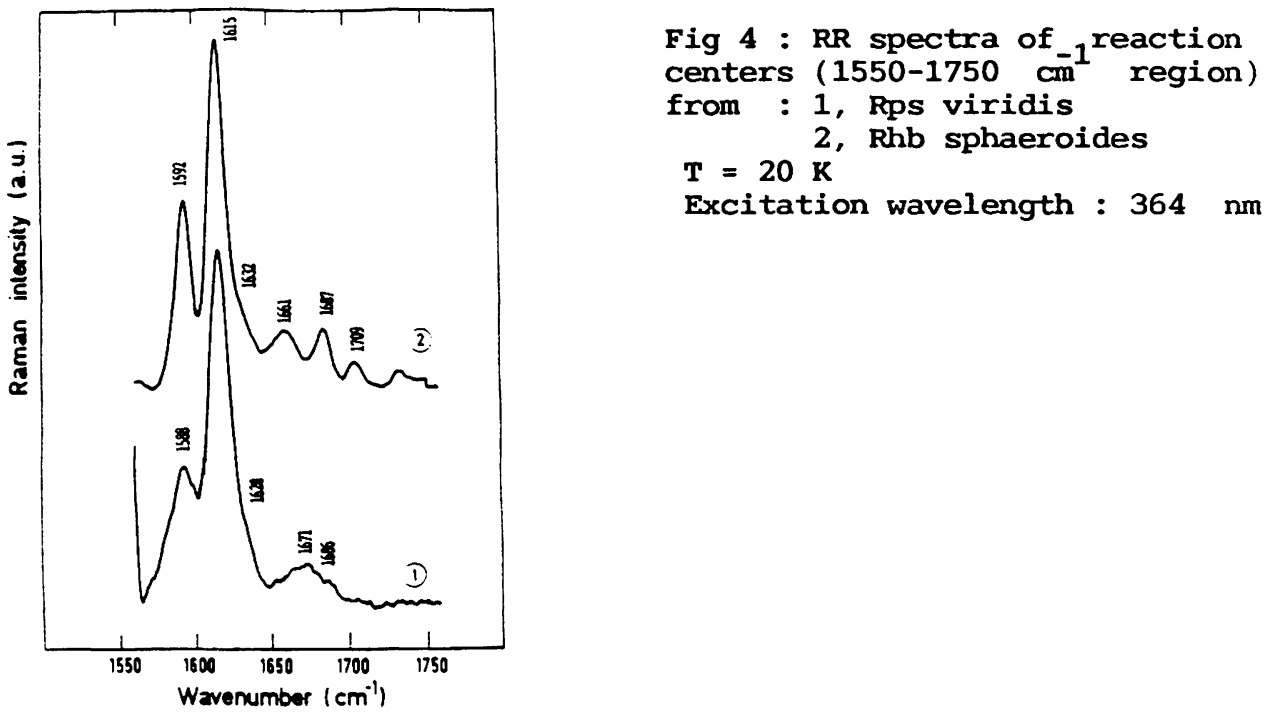

The frequencies observed in the carbonyl stretching region of the spectra only partially match with those observed for Rhb sphaeroides ( table 1). Some of these differences may not indicate differences in interaction states of conjugated carbonyls, but may arise from the above-mentioned difference in stretching frequencies of free_acetyl C=0 in BChl a and BChl b. For example, the 1670 and $1660 \mathrm{~cm}^{-1}$ features observed for Rps viridis and Rhb sphaeroides RCs, respectively, may both arise from interaction-free acetyl groups. On the other hand, the $1628 \mathrm{~cm}^{-1}$ frequency, which, in RR spectra of $\mathrm{Rhb}$ sphaeroides RCs arises from the $535 \mathrm{~nm}$-absorbing Bpheo (8), most probably arises, in RR spectra of Rps viridis RCs, from the primary donor $(6,9)$. A more detailed account of $R R$ spectroscopy of the primary donor of Rps viridis is given in these Proceedings (9).

\section{REFERENCES}

1) ROBERT, B. and LUTZ, M. (1985) Biochim. Biophys. Acta 807, 10-23

2) ROBERT, B, and LUTZ, M. (1986) Biochemistry 25, 2303-2309

3) LUTZ, M. and ROBERT, B. in : Biological Applications of Raman Spectrosc. (SPIRO, T.G. ed) John Wiley, New York (in press)

4) DEISENHOFER, J., EPP, O., MIKI, K. HUBER, R. and MICHEL, $H$. (1984) J. Mol. Biol. 180, 385-398

5) THORNBER, J.P., COGDELL, R.J., SEFTOR, R.E.B., PIERSON, B.K. and TOBIN, E.M. (1983) in Adv. in Photos. Res. (SYBESMA, C. ed) Vol. 2, pp 25-32

6) STEINER, R. and SCHEER, H. (1985) Biochim. Biophys. Acta 807, 278-284

7) STEINER, R. (1984) Thesis, Ludwig Maximilian Universität, München

8) LUTZ, M. and ROBERT, B. (1985) in Antenna Complexes and Reaction Centers of Photosynthetic Bacteria (Michel Beyerle, M.E. ed) pp 138146, Springer Verlag, Berlin

9) ZHOU, Q., ROBERT, B. and LUTZ, M. these Proceedings 


\section{INDEX OF NAMES}

\author{
Ailsil. R. I.5.577 \\ Abadia, J. III.4.325: III.10.751, 755: IV.4.2(1) \\ Abbott. M.S. IV.9.527 \\ Abdel-Rahman. M. III.l.29) \\ Abdourakchmanov. I.A. I. 4.415 \\ Abramowicz. D.A. I.5.597 \\ Ahresch. E.C. III.11.775 \\ Adamson. H. IV.8.483, 487 \\ Adawi. O. II.12.665 \\ Adir. V. III.11.791 \\ Agostiano, A. I.3.345. 344 \\ Akizawa. T. III.5.411 \\ Akerlund. H.-E. I.5.66.5; II.1.12.5 \\ Akesson. E. I.1.9 \\ Nlam. J. IV.12.797 \\ Alberte. R.S. I.1.83. 135 \\ Albertsson. P.-A. II..3.281 \\ Aldrich, J. IV.10.653 \\ Alegria. G.A. I.2.221 \\ Allied. D.R. II.t.293 \\ Allakhverdiev. S.I. I.5.581 \\ Allon. J.F. I.1.49: I.4.375: II.14.757, 761, 765: \\ III.11.831
}

Allen. K.D. IV.9.6(0)

Allen Jr., L.II. IV.5.25.3

Allred. D.R. II.13.697

Almon. H. II.12.6.37

Alscher. R. II.11.6(1): III. 2.260

Ambroz. M. 1.3 .315

Amesz. I. I.1.13. 29: I.2.18.5. 189: 1.4.4013, 4.35. 4.39

Ananver. (i.M. I.5.581

Anderson. (i. 11.9.525. 529)

Anderson. J.M. II.4.3(3)

Anderson. I..E. III.3.261. 269

Anderson. L..K. IV.12.817

Andersson. B. II.1.125: II.2.265: II.13.669.677

Andre. M. III.9.657

Andreasson. L.-E. I.5.5().3

Andreo, C.S. III.7.531

Andrews, T.J. III.9.601

Angerhofer. 1.1 .4 .427

Apel. I.J. III.1.71, 75

Arai. T. II.12.649

Arana, J.L. III.1.79

Arata. H. I1I.2.145

Arntzen. C.J. II.I.141: IV.10.679: IV.12.805. 813

Aro. E.-M. IV.2.115

\author{
Arrabaça. M.C. III.7.519 \\ Artandi. S. I.5.721 \\ Artus. N.N. IV.1.67 \\ Asama. K. III.9.577 \\ Ashby. M.K. IV.11.733. 737 \\ Ashour. N.I. IV.7.393 \\ Ashton. A.R. III.II.803 \\ Atkins. C.A. III.8.535 \\ Audren. H. IV.9.547 \\ Austin. R.B. IV.7.361 \\ Babcock. G.T. I.4.449: I.5.46.3, 471. 475. 479 \\ Bacholen. R. II.1.21 \\ Bader. K.P. I.5.549 \\ Badger. M.R. III.9.6()I \\ Baticr. L.J. II.1.117 \\ Bailly. J. IV.6.325 \\ Baker. N.R. II.5.359: II.11.557: IV.1.47. 75: \\ IV.9.597 \\ Balange. A.P. IV.S. 449 \\ Ball. J.T. II.11.5.53: IV.5.221. 225 \\ Barbato, R. II.3.277 \\ Barber. J. I.1.131: 1.2.257; 1.5.669: 11.1.89.93. \\ 97: 11.3.269: II.8.501; 11.15.8(19): III.11.779: \\ IV.1.91
}

Barker. R.F. IV.10.625

Bassi. R. II.1.61. 81: 11.3.277

Batuer. C.E. IV.II.699

Batumgartner, B.J. IV.10.683

Bazzaz. M.B. 1.3.297

Beale. S.I. IV.\$.431. 435

Beard. W.A. III.2.165

Bealuregard. M. II.12.625.629

Beechey, R.B. III.10.7+7

Beck. W.F. 1.5.499

Becker. A. I. $4 . .3 \$ 3$

Becker. D.W. IV .1.31

Bees. A. IV.8.t83

Behrens. P.W. II.11.593

Bendall. D.S. Il.7.485: II.10.549)

Bender. L. III. 4.363

Bennet. J. II.5.367: IV.9.531, 535

Berends. T. IV.9.511

Berg. S.P. I.5.589; II.4.317.321

Bergström. H. I.1.9

Berkowitz. G. IV.3.173. 177

Bernardes da Silva, A. III.7.519

Berry. E.A. II. 7.49.3: II.12.661

Berry. J. II.11.5.53 
Berry, J.A. III.5.387: III.9.597: IV.5.221. 225

Berry, J.O. IV.9.565

Berthold. I. II.7.477

Bertrand. M. IV.9.613

Berzborn, R.J. III.1.99; III.11.787

Betsch. T. III.9.56I

Bhogal. M. IV.1.91

Bickel-Sandkötter. S. III.I.17

Bickett. M. III.10.717

Biggens, J. II.14, 773. 777. 784

Bilek, O. I.3.315

Bisanz-Seyer. C. IV.9.547

Bishop. N.I. III.11.795

Bissig. R.A. II.1.13

Biswal. B. II.11.56.5

Billersmann. E. I.1.71

Björkman, O. IV.1.1]

Black. M.T. II.1.173: II.7.481; III.6.467

Blackwell. M.F. II.8.5()I

Blackwell. R.D. III.9.625

Blankenship, R.E. I.4.419: IV.11.74.5

Blevins. D.G. III.9.565

Block, J. 111.1.99

Bloom. M. III.10.693

Blyden. E.R. IV.10.617

Boegeman. S.C. I.I.119

Böger, P. II. 12.6.37

Bogorad, L. IV.9.519. 527; IV.10.66.3: IV.12.841

Bolhàr-Nordenkampf. H.R. IV .5.237

Bongi, G. IV.2.131: IV.5.241

Boote. K.J. IV.7. +15

Borchert. S. II 10.537

Borisov. A.Yu. I.1.41

Boschetti, A. IV.9.585

Boussac. A. 1.5.613

Bower. J. 11.11.6(1)

Bowes, G. III.5.399; IV.5.253; IV.6.345

Bowlby. N.R. I.5.693: 11.1.117

Bowyer, J.R. III.11.819

Boyer, J.S. IV.3.147.153

Bover. M. III.6.435

Boyer. P.D. III.1.123

Boyer. S.K. IV.8.511

Boxer. S.G. I.I.17

Bradbeer. J.W: III.4.333: III.6.483

Bradbury. M. IV.1.47

Brady, J. II.5.375

Brailsford, M.A. III. 10.747

Brand, J.J. IV.12.793

Braun. B.S. I.2.225

Brechignac. F. III.9.657; IV.6.341

Bredenkamp. G.J. IV.9.597

Breidenbach. E. IV.9.585

Breton. J. I.1.103. 107: I.2.177. 181. 261: I.3.329: 1. 4.387
Brettel, K. I.2.23.3

Briantais, J.-M. I.1.111: II.13.705

Bricker. T.M. I.5.6(1); 11.1.129)

Bright. S.W.J. I1I.9.629

Brock. H. I.I.6I

Brouers. M. II.12.645

Brown. A.I). IV.t.193

Brown. C.S. 111.10.725

Brown. J. II.I.18I

Brown. R.(j. I.1.99

Brown. S.B. IV.8.507

Bruce, D. II.14.773, 777

Brudvig, G.W. I.5.491, 499, (601. 6(15. (6)

Brunc, D.C. I.t. +19

Brunisholz. R.A. II.1.13

Brunke. K. III.6.490

Brusslan. J.A. IV.12.821. 825

Bryant. D.A. IV.10.6.59: IV.12.749. 757. 761. 76.5. 769

Buc. J. III.6.447

Buchanan, B.B. III.3.241. 249. 25.3: 1II.6.443. 487: III.10.729

Buchanan. S.K. 1.1.193

Buchholz. J. III.2.189

Budde. R.J.A. III.7.503

Budil. D.E. I.1.25: I.2.213: I. 4.36 .3

Buctow. D.E. IV 9.539

Bullerjahn. G.S. II.1.14.5: IV.12.773

Burchert. M. III.4.345

Burkey, K.A. II.5.243

Busconi. L. III.6.4.59

Butcher. K.S. 1.3.4.54, 349

Butler. W.M. I.5.725

Buurmeijer. W.F. II.5.38.3

Buzby. J.S. [V.12.75\%. 76]

Cadenhead, D.A. II 4.333

Callahan. F.E. III.II.799: IV.1..31

Callahan. P.M. I..3..325

Callegari. J.P. IV.7.399

(amilleri. P. III.1I.s19)

(amm. E.L. I.5.71.3

Cammack, R. IV 1.63

Cammarata. K. 1.5.617

Campbell, W.J. III.5.399; IV.5.253

(anaani. (). II.14.769)

Cannon. S. III.5.423

Cantrell. A. IV.10.0.59: IV.12.749

Canvin, D.T. IV.6.313

Carlson, J.L. III.11.763

Carmeli. C. III.1.12.3

Carpenticr. R. 1.5.6.33

Carr. J.P. IV.9.56.5

Cattolico, R.A. IV.I0.671

Ceccarelli. E.A. III.6.439

Celis. H. II.6.417; III.2.225 
(culemans. R. IV.7.411

(hadwick. B.W. 1.1.37: I.3.307: 1.4.4.31

(hain. R.K. II.7.465

(han, R.L. III.6. 4.39

Chandrashekar. T.K. I.5.463. +71, 475

Chang. C-H. I. +..36.3. 371

Chang. T.-E. IV.S.+23

Chang-Mei. L. I.5.585

Chaoving Zhang. I.1.37

Chapados. C. I..3..321

Chapman. D.J. I.5.669

Charbonmcau, S. II.14.777

Chazdon. R.I. IV.5.257

Chaves. M.M. IV.3.181

(hen. H.-Q. IV.9.539

(hen. J.-R. I.5.625

(heng. S.-H. III.9.637

Cheniac. G.M. I.5.617, 621: IV.1.31

Cherney. B. IV. I0.653

Chilu, E. II. +.333

Chiouhiat. A. III.11.827

Chisholm. D.A. IV.12.805. 8(1)9

Chitnis. P.R. IV.9.573

(hollet, R. III.7.503

Chou, Q. III.10.729

Christopherson. L. IV.10.0.53

(hun-hui. X. IV.2.99

Chrystal, J. II.1.189

Chylla, R. II.2.237

Clairmont. K.B. IV.8.5(13

Cleland. R.E. IV.1.27

Clement-Metral. J.D. III.6.455

Clemetson-Nussbaum J. IV.9.585

Cohb. A.H. III.10.705. 7(0)

(ollow, K. 1.5.733, 737

(ole. J. I.5.557. 569

Coleman, J.R. IV .6.325; IV.12.829.833

colcman. W.J. I.5.629)

(ollins. P.D. IV.9.557

Condon, A.(i. IV.5.20)

(omrads, J. III. 6.479

cook. W. B. IV.10.675

(o)mber, S.A. IV.11.733. 737

Cornell. B.A. II.S.509

Cornu. A. 11.5.371

Corradini. D. III.5.427

Cotton. N.P.J. III.2.127

Cotton. T.M. I.3.325. 333: I.4.423

(oughlan, S.J. II.10.545; II.15.797. 801

(ourtice. G.R.M. IV.10.625

(ox, R.P. II.14.789

Cramer, W.A. II.1.173: II.7.48I: III.6.467

Crawford. N.A. III. 3.241, 249. 253

Critchley. C. II.3.273: IV.1.27

Crofts. A.R. II.6.425, 429; II.7.493; II.12.661. 66.5
Crossland. L.D. IV.9.519

Crystall, B. I.1.1.31

Csaltorday. K. I.2.289.293

Cscke. C. III.10.729

Curtis. S.E. IV.I2.797

Cushman. J.C. IV.10.667

Czornuszewicz. R.S. I.5.721

Dai, II.P. III.1.37, 1033

Daldal. F. II.6.4(15: IV.11.7(1)7. 713

Daguenet. A. III.9.657

Damm. I. I1.1.137: 11.5.347. 351

Damoder. R. I.5.597

Danicll. H. IV.12.837

Darr. S.C. II.1.141

Davenport. J.W. III.1.61

David Britt: R. I.2.249: 1.5.557. 561, 56.5. 57.3

Davidson. E. IV.11.713

Davies, E.C. II.7.485

Davis, D. III.6. 435

Davis. D.J. II.7.473

Davis. E.A. IV.8.503

Dedner. N. III.11.787

Deisenhofer. J. I.4.353

de Jona. H. II.12.645

Dekker, J.P. I.4.435: I.5.533

de Kouchkovsky, Y. III.2.169

de la Torre. W. R. II 5.343

Delaunay, A.-M. IV.8.449

de Lorimicr. R. IV . 12.749

Delrieu. M.J. I.5.677

Demetriou. D.M. I.5.681

Demetriou. Y. I.5.479

Deng. X. II. 2.257

den Ouden. A. I.4.439

de Paula. J.C. I.5.491, (0)1. 605

Deprez. J. 1.1.103. 107: I.2.181: I.4.387

de Vitry. C. I1.1.105

DeVrics, S. Il.6.437

de Wannemacker. B. IV.7.394

DeWit. M. II.t.297

Dexheimer. S.L. I.2.249; I.5.557, 561. 56.5

Dicdrich-Glaubitz. R. I.5.519

Dierstein. R. IV.11.691

Dictz. K.-J. III.4.293, 329

Dilley, R.A. III.2.161, 16.5

Di Marco, G. III.5.427

Diner, B.A. II.I.105

Dismukes. G.C. I.2.193; I.5.487. 597. 721

Dmoch. R. III.11.787

Dobek. A. I.1.103. 107

Doman, N.G. III.5.431

Dominy, P.J. II.1.201: IV.1.35

Dorne. A.M. IV.9.547

Dörnemann. D. IV.8.491

Dostatni, R. II.6.421 
Drews. G. I.t.383: IV.11.691

Droppa. M. II.11.569

Droux. M. III.3.241. 249

Du. Z.Y. III.2.217

Dubbs. J.M. IV.12.715

Dujardin. E. IV .9.61.3

Dunahay. T.G. II.13.7()1

Dunn. P.P.J. IV.10.617

Durell. S. II.9.533

Dutton. P.L. I.2.217. 221, 225: 11.6.4(15. $4(1) 9$. +1.3. 4.37

Duysen. M.E. IV.9.6()I

Duysens. L.N.M. I.1.13, 185: 1.2.189. 229

Dyer. T.A. III.11.779: IV.10.617. 625

Dzelzkalns. V.A. IV.12.8+1

Eads, D.D. I.1.83, 135

Easterby. J.S. III.6.46.3

Eaton-Rye, J.J. II.6.+33

Eccles. C.J. IV.10.617

Eckert. H.J. I.5.545

Edclman, M. III.11.799

Edwards. G.E. III.3.257: IV .6 .357

Ehara. T. IV.9.609

Eichelmann. H. IV .5.24.5

Elcuterio. M. IV.11.699

El Hamouri. B. IV.7.4(17

Enami. I. 1.5.709

Engelbrecht. S. III.2.14I

Erdos. G. IV.9.539

Erokhin. Yu.E. II.1.17

Enfors. P. I.5.689

Etienne, A.-L. I.5.613: 1I.1.133

Edman. K. II.1.229

Espic, G.S. IV.6.313

Evans, M.C.W. I.1.99; 1.2.241, 245. 269

Even. D. IV.1.79

Fagenberg. W.R. IV. 0.353

Fahrendorl. T. III.10.73.5

Fajor. J. 1.3.307. 311

Falkowski. P.G. II.5.367: II.13.7.37

Farage. P.K. IV.2.131. 139

Farkas, T. II. 11.569

Farguhar, G.D. IV.5.2()9

Farrelly. D. IV.11.729

Fedenko. E.P. III.5.431

Feeney. J. III.5.395

Feher. G. I.4.375, 379; III.11.775

Feick. R. I.t.+(1)7

Ferris, K. I.2.193

Fetisova. Z.G. I.4.415

Feyen. J. IV.7.+11

Fichig, C. III.11.787

Figeys, H. III.11.827

Finke. W. III.1.99
Fischer, E. IV.5.281

Flanagan. L. B. IV.4.197

Fleck. I. III.10.759

Fleming. G.R. I.1.83, 1.35

Florensa. I. 111.10.759

Florin, S. 1.2.205

Flugge. U.-I. III.10.7.39

Fogel. M.F. III.9.597

Fonda. H.N. 1.4.449

Fong. F. K. I.3.345, 349

Ford, M.A. IV.7.361

Forseth. I.N. IV.4.205

Förster. V. I.5.511

Forti. G. II.13.721

Foster. J. IV.11.745

Foyer. C. III.4.309

Frackowiak. D. I.1.127

Fragata. M. I.3.337

France. L. I.I.II17

Franceschi. V.R. III.9.6.37

Frank, H.A. I.1.37: 1.3.307: 1.4.4.31

Frankel. L.K. II.1.129

Fransi. A. III. 10.759

Franzén. L.-G. II.1.125

Frasch. W.D. 1.5.693: II.1.117: 11I.1.71. 75. 119

Freas. S. III.5.387

Freiberg. A. 1.1.41, 45

Fricdrich. A. II.1.29

Fromme. R. III.11.783

Fructel. J.A. I.1.119

Fu-hong. Z. IV.2.99

Fujimura, Y. 1.5.701

Fujita E. 1.3.3017

Fujita, Y. I.1.91: II.1.157: II.13.737

Fuller, R.C. IV.11.745

Fung. M. IV.8.475

Furbank. R. III.4.30)

Fu-sheng. X. III.9.661

Gatlal, P. III..3.249

Gatdon. N. I.4.283

Ganago, I.B. 1.5.581

Garab. G. II.2.237; 11.10.5+1

Garg, J. IV.7.403

Gasparich. G.E. IV.12.76I

Gast. P. 1.2.237

Geacintov. N.E. I.1.10.3

Geiger. D.R. III. $4.3+1$

Genty. B. IV.3.169

Gerbling. K.-P. III.6.475

Gerhardt. V. II.8.505

Gerola, P.D. 1.3.341

Ghanotakis. D.F. I.5.463, 681. 689

Ghaus, H. IV.9.605

Ghirardi, M.L. II.2.261

Ghisi. R. III.3.265 
(ihosh, R. II.1.21

(iiacometti. (B.M. II.3.277

(iiangiacomo, K.M. II.6.409)

(iiardi. M.1. III.5.427

(iibbs, M. III. +.337

(iifford. R.M. IV .7..377

(iilloro, T. I.1.9.123

Gillott. M. IV.9.539

Gillgrich. J. IV.12.757

(iiorgi. L.B. I.1.95, 1.31: 1.2.257

(inard-Bascou, J. IV.10.655

(iiroud. C. 11.1.213

(iirvin. M.E. Il.7.481

Gijusen. K. IV.I.87

(jladue. R.M. II.11.593

(ilcason, F.K. III.11.76,3

(ileiter. H. 1.5.649

(ilick. R.E. II.2.253

Ginanam. A. III.7.515: IV.9.589. 593

(iodik. V.I. I.I.4l. 45

(iogel. (j. II.1.29

Golbeck, J.H. 1.2.253

Golden. S.S. IV.12.821. $\$ 25$

Gomez-Lojero. C. III.1.87

(ontero, B. III.6.447

(ionzalez. D.H. III.7.5.31

(iondchild. D.J. II.4.301

(rome. B.L. I.1.95. 131: I.2.257

Gotch. A.J. I..3.349

(iotow, K. IV .5.273

(iotliricd. D.S. I.1.17

Gounaris. K. I1.1.89.93.97: 11.8.501: 11.15.809

(iovindice, I.5.629: II.6.433

(ioval. A. IV.t.193

(irian. T. II.2.24l

Gräler. P. 1.5.519: III.1.25.91: 111.2.173. 177

(iral. J.A. I1.13.713

(irandoni. P. III.2.205

(irily, J.C. IV.10.617.625

(iray. K. III.6.4.35

(ircen. 13.R. I.5.713; II.1.19.3. 197: 1I.11.573: IV.9.577

(irecnbaum. N.L. II.1.65

(irecinc. B3. II.13.697

(irecr. K.I. IV.10.6.37

(irillith. ().M.

Grilliths, W.T. IV.8.469, 48.3

(irimme. 1..H. II.5.347. 351

(irodzinski. B. III.9.6+5, 65.3

Ciromet-Elhanan, Z. III.1.63

(iross. E. 11.9 .525 .529 .533

Cirossmann. A.R. IV.12.817

Girubas. P.M.G. II.13.721

(iruber. S.M. I.1.119)

Gunther. J.E. IV.4.189

Gugliclmi. (i. IV.12.749 (juikema. J.A. IV.12.789

Guiles, R.D. I.2.249: 1.5.557. 561. 56.5

Gui-Ying. B. IV.3.157

Gunner. M.R. I.2.217. 225: II.6.4(19. 413

Guo. B.J. III.2.217

Guralnick. L.J. IIl.7.523

Gustafson. S.W. III.4.273

Gutowsky. H.S. 1.5.629

Gutteridge. S. III.5.395

Guy. R.D. III.9.597

Habash. D.Z. IV.1.75

Haddy. A.E. III.1.119

Hachnel. W. II.8.513: II.9.521

Hagar. W.G. IV.8.503

Hageman. J. IV.9.569

Hagemann, R. III.11.783

Hague, A. IV.1.59

Hague. D.R. IV.9.557

Hala. J. 1.3.315

Halkier, B.A. II.1.49

Hall. D.O. II.12.641, 64.5: IV.1.39, 63

Hall. M.H. IV.7.360

Hall. N.P. III.9.611, 629

Hallick. R. B. IV.10.667

Hamilton. R.H. IV.12.757

Hangarter. R. III. 2.2(15)

Hanson. K. R. III.9.549

Hanson. L.K. 1.3.311

Hansson. Ö. I.5.5()3. 577

Hanssum. B. 1.5.515. 541

Haraux, F. III.2.169)

Harel. E. IV.9.573

Harris. G.C. III.6.491

Harrison, M.A. II.14.757

Harrsch. P.B. III.6.471

Hartman.F.C. III.6.451

Harvey, M.A. II.1.33

Hase. E. IV.9.6(19)

Hasclkorn. R. IV.12.821.825

Haska. G. II.1.16.5: 11.7.477

Hatrios. K.K. II.11.577

Häusler, R.E. III.7.527

Havaux. M. II.13.749

Havir. E.A. III.9.58I

Hayashi, H. I.1.3.3

Hayden. D.B. IV.1.47. 51

Heald. R.L. 1.3.33.3

Hearst. J.E. IV.11.717

Heath. R.L. I.5.717; I1.3.285: III.7.523

Heathcote. P. I.2.2()1; II.7.45.3

Heber. U. III. +.293: IV.2.1(17

Hecmskerk. J.W.M. II.1.205, 209

Heichel, G.H. IV.7.369

Heimann, K. III. 4.345

Heinze. J. I.3.329) 
Heinze, T. 111.2.189

Heldt. H.W. III.10.675

Hendrich. W. I.1.127

Hendry. G. IV.8.499

Henrysson. T. II.1.125

Heras, L. IV .4.201

Herrin, D.L. IV.10.6.37. 64.5

Heucr, B. III. 4.367

Hcupel. R. II.1(0.537

Hicrholzer. P.D. II.4.317. 321

Hilary, E. I.1.94

Hiller. R. III.1.123

Hiller. R.G. II.8.50)

Hincha. D. K. IV.2.107

Hinchigeri. S.B. IV.8.575

Hind, G. II. I0.541. 545: II 14.797. 801

Hinshaw, J.E. II.4.313

Hinz, U. II. 3.277

Hirasawa. M. III.6.4.35

Hird. S.M. IV.10.617. 625

Hisabori, T. III.1.13

Hirschberg. J. III.11.791. 807. 811

Hiyama. T. I.3.303: I.4.45; II.1.57

Hobbs, S.L.A. IV.7.385

Hodges. M. I.1.111. 115: II.13.705

Hocring. T.C. III.9.597

Holf. A.J. 1.2.197: 1. $4.399,4(13$

Hoganson. C.W. I.5.463, 479

Höglund. A.-S. IV.10.617

Høj. P.B. II.1.49

Hojer-Hansen. G. II.3.277

Holbrook, G.P. III.5.399

Holmes, N.G. 1.1.49; II.14.757

Holroyd, J.A. IV.8.507

Holt. R.E. I.4.423

Holten. D. I.2.169

Holtum, J.A.M. III.4.345: III.7.527: III.10.735

Holzwarth, A.R. I.1.53,61.67. 71

Homann. P.H. I.5.649.6.57

Hong. Y. III.2.149

Hong. Y.Q. III.2.217

Hope. A.B. III.2.149

Höplner, M. II.5.36.3

Horton. P. II.7.489; II.13.681; IV.1.59

Horváth. G. II.11.569)

Horváth. L.I. II.11.569)

Hoshina. S. II.11.581

Houghton. J.D. IV.8.507

Hoursiangou-Neubrun. D. II.1.221

Howell, D.A. II.1.16I

Howitz, K.T. III.9.593

Howley. K. II.5.375

Huang, D.-D. IV.8.423

Huault. C. IV.8.449

Huber. S.C. III.10.717. 725

Hubick. K.T. IV.5.2(0)
Huner. N.P.A. IV.2.119. 123. 127

Hunt. M.D. IV. 10.675

Hunter. C.N. I.1.13; III.11.779; IV.11.73.3. 7.37

Hunziker. D. 1.5.487.597

Husic, D.W. III.9.557

Husic, H.D. IV.6.317

Huppe. H.C. III.6.4+3

Iba, K. II.7.497

Idc. J.P. I.1.131: I.2.257

Igarashi. S. I.5.709

Ikegami. I. I.2.265: 1.3.303

Ikeuchi. M. II.15.805

Impens. I. IV.7.411

Inoue. K. II.1.45

Inouc. Y. 1.2.285: 1.5.645, 649, $6.53:$ II 1.5 .8015

Ireland. C.R. II 11.557

Isaacson. R.A. I.4.379

Ishikawa, H. IV.9.543

Islam. K. I1.13.715

lsmailov. M.A. I.2.161

Isogai. Y. I.5.483

Itoh. S. I. 2.26.5: I.5.483; II.7.497

Ivanov. A.G. II 13.741

lvey. S. II. 4.317 .321

Iwata. K. I.1.33

Jackson, J.B. III.2.127

Jackson. W.J. IV.11.721, 725

Jacob, J.S. II.1.217

Jacobs, F.H.H. II.1.2(05, 209

Jacobs, J.M. IV 8.4 .37

Jacols, N.J. IV.8.437

Jacquot. J.-P. III.3.241, 249

Jäger, U. IV.5.237

Jahnke, L.S. II.11.577. 589; IV .6..353

Jansson. C. I.5.697

Jaworskaya, V.K. III.5.4.31

Jennings. R.C. II.13.715

Jensen, K.1I. IV.10.6.37

Jensen, R.G. III.4.27.3. 281

Jian-ping, C. II 12.657

Jian-ping. X. II 12.6.57

Johansson, G. III.6.495

Johnston. A.M. IV.6.333

Jones. J.W. IV.7.415

Jones, R.W. II.7.441. 445

Junesch, U. III.2.173. 177

Jung Jin Oh. I.1.37

Junge, W. I.5.511: III.2.13.3, 141

Kaderbhai, N. III. I().747

Kacthner. T.M. IV.10.617

Kafalieva, D. II.13.741

Kagan-Zur. V. III.4.289

Katiseva. E. II.14.793 
Kajiura. H. I.5.701

Kallas, T. IV.12.801

Kalt-Torres, W. I11.10.717

Kappitan, S.W. III. 4.341

Kaplan. A. IV.6.289, 297, 301

Kapsa, V. I.3.315

Karchenko, S.G. I.4.415

Karukstis, K.K. I.1.119

Kalrunen. P. IV.2.115

Kasemir. H. IV.9.561

Kasino, Y. I.5.625

Kassumov. K.K. III.5.431

Katoh. A. II.1.45

Katoh. S. I.5.625, 709; II.1.77

Kawamura, H. IV 9.543

Kecle, D. III.9.633.637

Keegstra. K. IV.9.569

Kelley. S.R. III.11.8.31

Kendall, A.C. III.9.611. 629

Kessissoglou. D.P. I.5.725

Key. J.L. IV.2.143

Keys. A.J. III.5.395; III.9.611.629

Khatari-Nejad. R.A. IV.7.419

Kicleczawa. J. II.11.585

Kiirats. A. IV.5.24.5

Kirmaier, C. I.2.169

Kirschbaum. M.U.F. IV.5.257. 261

Kitaka. S. III.9.577

Kitayama, M. III.6.499

Klaver, J.C. IV.1.43

Kleczkowski, L.A. III.9.565

Klein, M.P. I.2.249; I.5.557. 561, 565, 573

Klein. R.R. IV.9.511

Klein. U. III.10.713

Klessig. D.F. IV.9.565

Klimov. V.V. I.5.581

Kloppstech, K. IV.1.79

Klug. D.R. I.1.95, 1.31: I.2.257

Klug. G. IV.11.691

Knall. D. III.6.435: IV.11.745

Knobloch. K. III.2.229

Knoctzel. J. II.1.137: II .5.351

Knoppik, D. IV.5.229, 233

Knowles, V.l. III.10.693

Knox. R.S. I.t. 445

Kobayashi, H. III.5.411

Kobayashi. M. 1.3.303

Koenig. F. IV.1.95

Koike. H. I.5.645

Kojima. Y. II.1.57

Kolaczkowski. S.V. I.1.25; I.2.21.3; I.4.363

Kolbowski. J. II.13.745

Komatsu-Takaki. M. III.1.45

Kopeliovitch. B.S. III.2.153

Koppenaal, F. II.1.177

Kosower. N.S. III.3.253
Kotzabasis. K. IV.8.491

Kovacs, G. 1.2.221

Kozicradzki, I. IV.10.687

Kozubek. A. II.11.585

Kraayenhof. R. II.1.177

Krab, K. II.1.177

Kramer. D. II. 12.665

Krause, G.H. IV.1.19

Krause. H. I.1.87; II.8.505

Kreimer, G. III.4.345

Kreutz, W. I.2.177; I.3.329: I. 4.383

Krishnan. M. IV 9.589, 593

Krishnan, V.A. III.7.515

Krishnasamy, S. IV.9.593

Krogmann. D.W. IV.12.797

Krol. M. IV.2.123. 127

Krstić, B. IV.7.395

Krupa, Z. IV.2.119

Ku. M.S.B. III.9.637; IV.6.357

Kuang. T.Y. II.13.729

Kubo. A. II.1.45

Kubo, S. IV.9.543

Kuhlbrandt. W. I.1.131; I.4.443

Kulig, E. II.11.585

Kull. U. II.13.713

Kumar. A. III 4.363 ; IV.7.4(1)3

Kumpl, B. II.1.153

Kurucsev, T. I.3.337

Kusunoki. M. 1.5.729

Kuwabara, T. I.5.705; IV.10.629

Kyle, D.J. II.11.593

Lalasch. H. IV.1.19

Lacoff. N.M. 1.2.289

Laczko. I. II.14.793

Laisk. A. IV.5.245

Lampton. J.D. III.1.57

Lannoyc. R. III.11.827

Larkum. A.W.D. II.1.189

Larrinua. I.M. IV. I(1.640

Larsson. U.K. II.2.253; II.13.669, 677

Latzko. E. III.4.345: III.6.475; III. 7.527: III. 10.73.5

Laudenbach. D.E. IV.12.797

Lavorel. J. I.5.613, 673

Lawlor. D.W. II.5.359: III.9.66.5

Lawyer, A.L. III.11.831

Lca. P.J. III.9.625, 629

Lcblanc. R.M. I.1.127: 11.12.625.629

Lec. P. IV.1.59

Lee. S. IV.9.539

Lee. S.A. III.11.819

Lec, W.-J. II.2.233

Lemaire. C. IV.10.655

Leu. S. IV .9.585

Lehnherr. B. IV.5.283 
Lemicux. S. 1.5.63.3

Lemoine. Y. II. 1.105: II.5.371

Lerma. C. III.I.87

Levine. L. 1.2.169

Li. D.Y. $111,1.37$

L.i. X. 1.5 .725

Li. Y.-s. III. +.337

Li. Y.Z. 1II.2.217

Licbetinz. R. IV.11.691

Lill. H. III.2.133, $1+1$

Lilley. R.MCC. IV.4.193

Lin. S. 1.4.445

Lin. S.Q. I1.13.729

Lin. T.P. III. 10.693

Lips, S.H. III.4.289

Ljunberg. U. II.1.121. 125

Loach. P.A. 1.3.325: 11.1 .25

LoBrutto, R.L. I.2.217

Lockall. W. II.1.37

Lockhart. D.J. I.I.17

Long. S.D. II.11.557: IV.2.131. 139

Lorimer. G.H. III.5.387

Lottspeich. F. I.4.407

Lous. E.J. 1.2.197: 1.4.399

Low. P.S. IV.2.127

Luciss. W.J. IV $6.3+1$

Ludgar. M. II.6. +17

Ludlow, M.M. IV.3.161

Lukens. J.H. IV.9.519

Lukow. L. III. 4.345

Lundegardh. B. $111.11 . \$ 23$

Lutz. M. I.4.395. $4+1$

MacDonald. F.D. III.10.729

MacFarlane, J.F. IV .6.3.33

Mache. R. IV.9.547

Machold, O. II.1.113

Macioszek. J.A. III.3.261

Mackic. N.D. II.3.273

Macnal). F. II.5.359

Madore, M. III.9.6+5

Malechler, F. IV .5.283

Milhon. J.D. IV.7.385

Maison-Peteri. B. I.5.613, 673

Maiisson. E. IV.2.119. 123. 127

Malck. L. IV.10.687

Malkin. R. II.7.465: IV.12.801

Malkin. S. II.13.749

Malyan. A.N. III.1.21

Mannal Mannan. R. IV.9.589. 593

Manodori. A. II.2.249

Mansficld. R.W. 1.2.241, 24.5

Mäntele. W. 1.2.177. 261: I.3.329: 1.4.383

Mara, H. II.1.29

Marcus. F. III.6.+71

Marcus. Y. IV.6.3()1
Marder, J.B. 11.1.89

Marengo. T. IV +.193

Maróti. P. II.6.t(1)

Marquez. I.A. III.3.261

Marrs. B.L. IV.11.699

Masamoto.K. II.I.149)

Masojidek. J. IV.1.55

Massalcci. A. III.5.427

Massenet. O. IV.9.547

Masson. K. II.6.+21

Matthijs. H.C.D. II.10.545

Mathis, P. 1.2.151. 233

Mattoo. A.K. III.11.799

Matuzerall. D. II.1.65

Mavankal. G. 1.5.661

Mawson. B. IV.5.27.3

Malyer. S.M. IV.8.+35

McCain. D.C. I.5.66)

McCarty. R.E. III.1.57, 61: III.9.593

McCauley. S.V. II.2.245: II. $+.3(1) 5$

McComb. J.C. II.6.387

McDermolt. A.E. 1.2.249: 1.5.557, 561. 56.5

McFiadden. B.A. III.5.419. IV.12.837

Mchale. N.A. III.9.58I

Mcinory. S. IV.6.333

Mclaaughlin, A.C. 1.2.217

McLaughlin. W.E. IV.10.649

McMorrow, E.M. III.4.333: III.6.48.3

Meck. E. II.13.709

Meck. J. III.5.387

Meiburg. R.F. 1.t.403

Mejia. A. III.1.75

Melandri, B.A. III.2.193

Melis. A. II.1.185: II.2.245. 249, 253, 257. 261. 265: II. $+.305:$ II $.5 .355:$ IV.1.27: IV.4.189

Melkonian. M. III. $+.3+5$

Mellvig, S. III.4.317

Mende. D. I1.7.481

Merchant. S. IV.10.66.3

Merlin, E. IV.10.65.3

Merritt. S. 1.5.689

Mets. L.J. I.1.8.3. 135: III.9.6.33. 6.37

Me1\%. J.G. IV.10.679)

Meunier. C.P. I.5.733. 737

Mever. D. III.6.t67

Mever. H.E. III.1.99: III.11.787

Michel. H. I. . .353: III.11.771

Michel. H.P. IV.9.585

Middendorf. T.R. I.1.17

Miginiac-Maslow, M. III.3.241. 249

Miles. D. III.1.53: IV.10.675

Miller. A.-F. 1.5.601

Miller. K.R. II.1.217: II.4.309, 313

Miller. M. II.14.789

Miller. T.E. IV. 7.361

Millner. P.A. II.1.89: $11.15 .8(19$ 
Mills. I.D. III.I.49; III.2.2(1)

Mills. W.R. IV.I0.683

Mimura. M. I.l.9)

Minami. E.-i. IV.10.620

Mitchell. R. II.8.513: II.9.521

Mitsui. A. II.12.649

Mivachi, S. IV.s.t.54

Miva(0. M. I.5.4.5. 613. 7011. 7(15)

Mivantia. T. I.5.7(0)

Miziorko. H.M. III.5.4(0.3

Mohanty. N. II.11.58!

Mohanti. P. II.11.581. 597. 605

Moller. B.L. II.1.49

Molnar. S.A. II.9.525

Moncll. C.R. I.1.119)

Monge. E. IV.t.2()I

Monroy. A. IV.9.5si

Monson. R. K. III.9.6+1

Moore. B.d. IV.6.357

Moore. A.L. III.4.350

Morishige. D. II.13.697

Moore. A.L. III.9.35.5. 589

Morgan. C.L. IV.7.361

Morones. J.V. IV.6.317

Morrill. M. III.10.693

Morrisicy. P.J. Il.4..305

Morsc. P.D. II.12.66.5

Muser. (.C. II.6.413. 4.37

Moss. D.A. II. 7. $+53,+61$

Moualem-Beno. D. IV.t.185

Mousscaul A. II.1.221

Moya. I. I.1.111. 115: 11.13.705

Mucller. J. IV.5.283

Mukherjec, U. III.10.735

Mulinciux. ( .W. II.14.757.765

Mullet. J.E. IV.9.511

Mullin. (.A. IV.12.757

Mumma. R.(). IV.12.757

Murasc, M. IV.I0.629

Murata. N. 1.5.4.53. 61.3. 7(1). 705: IV.10.629)

Muratia. T. I.5.7(15)

Murphy, R.(. IV.12.769)

Murray. A.J.S. III.9.625

Muschinck. (;. III.3.26)

Muskavitch. K.M. IV.9.519

Myall. I.F. III.2.127

Viabedryk. E. I.2.177. 261: 1.3..329: 1.4.387

Vaber. J.D. III.11.767

Valgall. R.T. IV.2.14.3

Nakazato, M. I.3.3(1)3

Ninbal. (). II. I.69

Nealc. P.J. II 5.555

Nechushtai. R. II.1.41: IV.9.573

Nedbal. L. IV.1.55

Neimanis. S. III. 4.293
Neuhaus, H.E. III.10.7.35

Neumann. K.H. III.4.36.3

Newell. W.R. II.3.2(10)

Newman. S.M. IV.10.671

Nicholson. S. III.6. +6.3

Nicderer. E. II.1.13

Nicderman. R.A. I.1.29: IV.11.729)

Nier. W. HI.1.99

Niggemeyer. S. III.1.29

Nikolau. B.J. IV.9.565

Nilsen. S. IV.1.87

Nishimura, M. 11.7.497

Nishio, J.N. III.7.523

Nitschke. W. II.1.37. 165: II.7.477

Nixon, P.J. III.11.779)

Noctor. G.D. III.1.49

Nocsberger. J. IV.5.283

Noguchi. T. I.1.33

Norden. B. 1.3..337

Norris. J.R. 1.1.25: 1.2.213: 1.4.36.3. 371

Nour. T.A. IV 7.393

Nugawcla. A. IV.2.131

Nugent. J.H.A. I.2.2+1; II.1.9

Nuijs. A.M. I.2.185. 229

Nurmi. A. II.5.339

Nutt. H. II.1.53

Oelmüller. R. IV.9.561

Octumcier. W. II.6.421: 1II.11.815

Ogawa. T. IV.6.297. 301. 309)

Ogren. W.L. III.5.371. 379

Ohad. I. III.11.791: IV.1.79

Ohadd. N. III.11.8(17. 811

Oh-Hama, T. IV.8.44.5

Ohki. K. II.1.157

Oja. V.IV.5.245

Okamura. M.Y. I.4.379: III.11.775

O'Kecle. D. II.7.469)

Olive, J. 11.4.325, 329

Oliver. D.J. III.9.569.573

Olson. J.M. I.3.3+1

OMalley, P.J. I.5.46.3, 475

Omata. T. IV.6.30) .309

Ono. T.-a. 1.5.6+9. 6.53

Öquist, G. IV.1.I

Ort. D.R. II. 2.241: III. 2.20.5: IV.2.103:

IV. 3.153

Ortiz-Lopez. A. IV..3.153

Osafunc. T. IV.9.6(1)

Osmond. C.B. IV.3.157

Otto. J. III.1.99

Outlaw Jr.. W.H. IV.5.26.5

Oworah-Nkruma. R. III.I.\%)

Owens. T.G. I.1.8.3, 1.35

Owttrim. G.W. IV.12.833

Oxborough. K. II.7.489 
Packer. N. IV.S. 487

Packham. N.K. IV.I.71

Padclock. M.L. III.11.775

Pakrasi. H. IV.10.679

Pakrasi. H.B. II.2.233: IV.12.813

Paliwal. R. II.11.561

Palta. J.P. IV.2.111

Pancoskal. P. I.3.315

Panncels. P. III.11.827

Papageorgiou. G.C. II.14.78.5

Parctt. K.(i. 1.2.253

Parkash. J. II.3.289)

Parkes-Loach. P. II.1.25

Parry. M.A.J. III.5.395: III.9.011: IV.7.361

Passera. C. III.3.265

Patc. J.S. III.8.535

Patcl. M. III.9.585

Patcl. P.K. II. I().549

Patric. W.J. III.1.53

Pearcy. R.W. IV.5.257

Pecker. I. III.11.807. 811

Pecoraro. V.L. I.5.725

Pedersen. J.P. I.3.3+1

Pedersen. J.Z. II.14.789

Pelant. I. I..3.315

Pelticr. G. II.12.653

Percival. M. IV.1.47

Persson. L..-O. III.6.495

Peter. G.F. II.1.101

Petersen. J. 1.2.237

Pelerson. C.C. II.I.4l

Peterson. R.B. III.9.54): IV.5.21.3

Petrouleas, V. I.5.721

Phillips. A.L. III.9.611

Pick. U. II.1.93.97

Picorel. R. 1.4.423

Picr. P.A. IV.3.17.3

Pierce. J. III.5.387

Pietrobon. D. III.2.193

Playl. L.A. IV.12.785

Platl-Aloia. K.A. II.3.285

Plijter. J.J. 1.4.4.35. 4.39: I.5.5.33

Plumley. F. (j. II.15,8(15: IV.10.6.37

Podestal, F.E. III.7.5.31

Ponsc, G. 111.2.157

Popova. L.P. III.9.669

Popovic. R. 11.12.625. 629

Poporic. Z. I.2.221

Porter. G. 1.1.95, 1.31: 1.2.257

Porter. M.A. III.6.451

Porter. R.D. IV.12.757. 76I. 769

Portis Jr.. A.R. III.4.367: III.5.371. 379. 383: IV.2.103

Post. A. II.s.5(1)

Powls. R. III.6.46.3

Preiss. J. III. 10.693. 701
Preston. C. 11.3.273

Preusse, S. III.11.815

Price. ( .A. IV.10.667

Prince. R.C. IV.11.721.725

Prioul. J.L. IV.9.553

Proudlove. M.(). III. 4.359 : III.9.585. 589

Punnetl. T. II.5.375: II.13.753

Qian. T.Q. III.I.103

Qi. S. I.5.585

Qiu-chen. C. 11.12.6.57

Ouick. W.P. III.2.2()]

Quinto. I. III.2.225

Radmer. R.J. II.11.593

Radunz. A. IV.9.613.617

Raliales. M. III.10.759

Randall. D.D. III.9.56.5

Ranger. C. III.9.657

Rato. I.M. III. 4.325: III.10.751. 755: IV.3.147

Riı). K.K. II.12.645

Raschkic. K. IV.5.281

Rasshan. F. I.3.329

Raltajczak. R. I1.9.521

Raven. J.A. IV.6.333

Ralvencl. J. II.12.653

Ravizinni. R.A. III.1.79

Ralynes. D.A. III.4.27.

Robanc. K.K. I.I.41

Rebciz. C.A. IV.S.4.39

Reddy. K.J. IV.12.773, 777

Redlinger. T.E. IV.11.7+1. 74.5

Rees, D.C. I. $4 . .375$

Reimer. P. IIl.11.827

Reinhold. L. IV.6.289. $3(01$

Reiskind. J.B. IV.6.375

Roith. M.E. IV.12.797

Remy. R. I.1.115

Renger. (9. 1.5.515.519. 541. 545: 111.11.753

Rensing. L. II.1.137

Revss. $\wedge$. IV.9.553

Riciard. I. III.6.447

Riccolonono. J. II.1.25

Rich. P.R. II. 7.453, 461

Richards. G.E. IV.1.39

Richards. R.A. IV .5.2(19)

Richards, W.R. IV.8.475

Richter. M. II.5.363

Richter. M.L. III.1.57

Ridley. S.M. II.1(1.540

Ries Ji.. H.E. II. 4.333

Ricthman. H.C. II.1.145. 149: 11.5.379):

IV.12.773

Rikin. A. IV.9.581

Rivicre. M. III.6.4+7

Robert, B. I. $4.395,4+1$ 
Roherts. D. IV.2.12\%

Roherts. J.K. IV.2.143

Roluctson. D.E. I.2.217: II.6. $4(15, f(1), 4.37$

Robinson. ('. IV.9.569)

Robinson. H. II.6.429: IV.12.855

Rohinson. J.M. III.8.54.5

Robinson. S.J. IV.11.7+1

Rodirmel. S.R. IV.9.519

Rodrigues. M.L. IV.3.Is'

Rolrigucz. I.D. I.5.46.3. 471. 475

Roclols. T.A. II.5.38.3

Rögner. M. III.1.25

Rominowski. M. I.1.127

Romero. I. 111.2.225

Rongey. S.H. III.11.775

Root. S. IV.11.713

Ro()l. L.L. 1.2.253

Rosimann. D. IV.9.561

Rosengaud. F. I.5.677

Ross. D. IV.1.71

Roux. E. 111.2.213

Roy. 11. III.5.+23

Rovicr. (C. IV 9.547

Rüdiger. W. IV.s.t6)

Rühle. W. II .5.36,3

Rumberg. B. I11.2.155. 189

Rurainski. H.J. II.10.537

Russcll. D.R. IV.9.5[9

Rutherford. A.W. I.2.2(1). 277: I.5.653

Silad, A.O.M. 1V.7.393

Silball. S.C. 11.11.581

Silge, R.F. III. +285

Silnis. J.K. III.6.491

Silkurai. H. II.1.57: III.1.13

Salis. P. III.11.\$27

Silnikow. I. I.5.697

Sillucedi. M. [:. III .5.371. 379

Sinders. (.I. 11.14.757.761

Sindström. A. I.1.123

Simlos. ('.P. IV.1.6.3

Saric, M.R. IV.7.395

Silrojini. (i. III.9.569. 57.3: 11:12.837

Sissenrath. (j.F. IV.2.10.3

Silloh. K. I. 4..379: I.5.4\$.3, 625, 7(19): II.1.69, 7.3. 77

Saller. K. 1.1.139: 1.2.240:1.5.557. 561. 565. 569.573

Sinille. B. IV.12.829

Salver. D.T. I.5.717

Sillecel. S.A. II.II.605

Salygin. (). 1.5.523.5.37

Sichatt. (i.H. 1.1.61.67

Sihecr. H. 1.1.14.3: I.t.411

Scheijen. M.A.M. II.I.2()

sihellezsk. B. 11.5.347
Schcibc. R. III..3.233

Schill. J.A. IV.9.(O)

Schilfer. M. I. 4.36.3. 371

Schickler. H. III.2.153

Schlodder. E. I.5.523

Schmid. (j.H. I.5.549: III.9.617

Schmidt, (j. III.1.9)

Schmidt. G.W. II. 15.805: IV.10.6.37. 645

Schmidt. W. IV.S.491

Smith. A.(j. IV.I0.617

Schmitt. J.M. IV.2.107

Schncegurt. M.A. IV.8.431

Schoenknecht. (i. 111.2.133

Schonlicld. M. III.2.153

Schröker. W.P. I.5.665

Schroeder. H.-U. II.1.37

Schüll. H. III.I.17

Schumann. J. III.I.9

Schuster. (i. IV.1.79)

Schwarm. H.-M. 1II.2.229)

Schwarl\%. P. II.1.29)

Schwartzbach. S.D. IV.9.581

Schwender. J.R. IV.9.535

Schwerzmann. R. II.1.21

Secmann. J.R. III.4.2S5. 321

Seftor. R.E.B. III.4.273

Seibert. M. I.4.423: 1.5.589. 67.3: 11.4.297: IV.10.679

Selinger. H. IV.5.229. 233

Selstim. E. II.1.225. 220)

Senger. H. I.I.7I: IV.S.59)

Sen-Ciupta. A. IV.3.177

Scrrano. A. III.6.439

Servaites. J.C. 111.5 .391 .395

Setil. P. I.2.233

Selman. B.R. III.1.107. 111

Selmin-Rcimer, S. III.I.111

Senge. M. IV.S.t)]

Senger. II. IV.s.t9)

Setlik. I. IV.1.55

Setlikoví. E. IV.1.55

Selo. II. IV.S.+45

Shalicy. M.A. I.5.58I

Sharkey. I.D. IV.3.157

Sharp. R.R. I.5.553

Shaw. E.K. IV.9.5.35

Shealler. C.C. IV .7.369

Sheats. J.E. I.5.721

Sherman. L.A. 1I.1.145. 149: 11.5.,379

Shimizu. T. II. 1.45

Shinohara. K. IV.9.539: IV.10.629)

Shinozaki. K. I.5.7(1)

Shiozawa. J.A. I. $4.4(07$

Shkuropalox. A.Ya. I.2.161

Shahak. Y. III.I.HI

Shapes. R.J. II.6.387. 397 
Sharkey. T.D. 111.4.285. 321

Sharp. R.R. III.1.71. 119

Shavil. N. III.I.I

Shealler. C.C. IV.7.469

Shen. J.Y. IV.9.519

Shen. Y.K. 111.1.37. 1113

Sheng. J.-S. IV.12.793

Sherman. L.A. IV.12.773. 777. 78.

Shi. D.J. II. 12.641, 645

Shingles. R.A. III.9.(64.5

Shinohara. K. IV.9.5.39: IV.10.629

Shomer-Ilan. A. IV.4.185

Showell. M.S. I..3..349

Shu-jun. Li 11.12.657

Shuvalov. V.A. I.2.161. 229

Sibbald. P.R. II.11.57.3

Sidler. W.A. II.1.153

Sicburth. L.E. IV.9.531: IV.10.637

Siegenthaler. P.-A. II.I.213

Sigalat. C. III.2.169

Simkens. E. IV.7.399

Simon. J.P. IV.7.399

Simpson. D. I.3.3(17: 11.1.61. 81: 1I.3.277

Sinclatir. J. II.13.733

Singhal. G.S. II.3.289: II.11.561

Sinning. I. III.11.771

Sivak. M.N. III.t.301. 313

Skala. I. I. 3..315

Stanković. Z.S. IV.7.495

Slooten. L. 11.12.633: III.1.95

Slovacek. R.E. II.1.33

Smeckens. S. IV.9.560

Smil. H.W.J. 1.2.189. 229

Smith. A.G. IV.S.4.3: IV.10.717

Smith. B. II.1.18.5

Smith. K.M. I.3.307

Smith. N.S. I. 2.245

Smrckit. A.V. III.4.281

Snel. J.F.H. II.12.613. 617. 621

Snyder. U.K. II.14.78t

Solrovii. D. IV.1.55

Soloriv. A.A. 11.1.17

Somersilo. S. IV.2.115

Somerville. C. IV.1.67

Somerville. S.C. II.1.1+1

Soncini. F.C. III.6.4.39

Sotiropoulou. (j. Il. 14.785

Souctiova, L. 1.3.315

Soulic. J.-M. III.6.447

Spalding. M.II. IV.6.329

Spangfort. M. II.2.26.5

Spano. A. IV.9.6(1)5

Sparrow. R. I.1.\%)

Spear-Bernstcin. L. 11. $4.3(1) 9$

Spencer. L. I.5.717

Spilatro. S.R. III.1().7()I
Spiller. S. IV.I2.S(1)

Spillmann. A. II.ร.513

Srinivasan, A.N. 1.5.553

Stachon. D. IV.S. +23

Stachelin. L.A. II.4.293. 297: 11.13.697. 7111: IV.9.(2)1]

Stanković. Z.S. IV.7.395

Steck. K. 1.t.383

Steflen. K.I. IV.2.111

Scchlik. D. I.2.2.37

Stcin. M. III.6.4.59

Stcincr. R. 1.4.t11

Stcinmet\%. D. Il.5.347

Sicup. M. III.6.475. 470

Steven. P. I.5.589)

Stevens Jr.. S.E. IV.12.749. 757. 761

Stcwart. (i.R. III.9.585

Stirewalt. V.L. IV.12.749

Stitt. M. III.11).675. 685

Strasser. R.J. II.13.709. 713.717

Straus. N.A. IV.12.797. 829

Streusand. V.J. III.5.383

Strotmann. H. III.1.29; III.2.157

Sturtevant. J.M. I.5.6()9

Siyring. S. II.1.133

Sukenik. A. II 5.567

Sukumaran. D.K. II.3.289

Sumar. N. 111.9.585

Sumida. S. IV.9.6(1)

Sundby. (: 1I.13.669.677

Sundström. V. I.1.9. 123

Surck. B. III. 4.345

Suril. M.B. IV.0.333

Sutcr, F. II.1.13

Sutton, A. IV.9.5.31

Suzuki. K. IV.0.329)

Siensson. P. II..3.28I

Swenson. S.I. I.5.733. 737

Sibesma. C. II.12.633

Syllabil. A.H. I1.11.593

Szalewicz. A. 11.11.585

Szcepaniak. A. 1.1.127

Tahi. M. III.2.22I

Taha. J. IV.7.4(1)

Takabe, T. IV.9.543

Takahashi. Y. II.1.73

Takamiya. K.-i. 11.7.497

Tamai. N. I.1.91

Tamura. N. 1.5.621

Tang. C.O. II.13.729

Tang. J. I.4.363. 371

Tane. P.S. II.12.64l

Tang. X.-S. I.5.483

Taoka. S. II.6.475

Taremi. S.S. I.4.4.31 
Tasumi. M. I.1.3.3

Taritian, B.A. I.2.177. 261: 1.4.387

Tavkr. M.A. III.2.127

Tavkr. S. IV.5.273

Taiylor Eighmy. T. IV.6.353

Pellice. A. II.13.689

Terishima. I. IV.5.20)

Terris. M.11. I.1.119

Terry. N. III.4.325: 1II. (0).751. 755

Thalooth. A.T. IV.7.593

Theg. S.M. III.2.161

Thewalt. M. II.14.777

Thibault. P. I.5.549

Thoma, W.J. III.11.76.3

Thomas. F. IV $9.5+7$

Thomals. J.C. II.1.221

Thompson. A.G. III.10.747

Thompson. J.E. IV.2.127

Thompson. L.K. I.5.6(1)

Thompson. M.A. I..3.311

Thomson, W.A. II.3.28.5

Thornber. I.P. II.1.41. 101: IV.9.573

Thulke. (i. III.2.177

Thurnatuer. M.C. 1.2.237

Tiede. D.M. I.2.2(15: 1.4.36.3. 371

Timpman. K. I.1.41. 45

Ting. I.P. III.7.523

Ti Tien. H. I.2.2(09

Tohin. A.K. III.9.585. 589

Togasaki. R.K. III.6.499

lollort. N.E. III.9.557: IV.6.317

Tominaga. M. III.9.577

Tomoaia-Cotiscl, M. Il. 4.333

Ting. B.X. III.2.217

Torres-Ruiz, J.A. III.5.419

Tram. V.D. III.2.221

Tran-Anh. T. III.2.185

Jrohst. A. II.1.109)

Tripathy. B.(. IV.S.439)

Tromp. V.A. II.I.2(15)

Isio. J. I.5.487

Tisones. T.D. III.9.669

Trissl. H.-W. I.2.181

Tucci. M.A. III. 4.341

Tukadal. S. IV.9.609

Turner. J.(. III.9.629)

Tys\%kicwic\%. E. III.2.213

UnmiNair. B.C. I.5.721

Upham. B.L. II.11.577

Usuda. H. III.7.5()7: III. I(1.717

Vacck, K. I.3.315

Vaklinova. S.G. III.9.6(6)

Vall. J. IV.t.2()

Valle. E. III.5.411
Vallejos, R.H. III.1.79: III.6.4.39

Vallon. O. II. +.329

Van. T.V. III.2.189

van Berkel. J. III.6.479

van Berkum. P. III.S.5+5

van Brakel. G.H. I.3.3+1

van den Branden, S. III.1.95

van den Brock. L. IV.7.399

van den Driessche. H. IV.7.411

van der Hocven. M.F.R. I.2.189

van Dorssen. R.J. I.1.13. 29: I.4.4.35. 439

van Gorkom, H.J. I.2.229; I.4.435, 4.39;

I.5.533

van Grondelle. R. I.1.1.9, 13, 29

van Kooten. O. II.12.613.617.621

van Moer, A. III.11.827

Vann. C.N. IV.12.777. 785

Vanngard. T. I.5.577

Van Rensen. J.J.S. III.11.767: IV.1.4.3

Vasmcl. H. I.2.185; 1.4.4(1)3

Vass, I. I.5.649

Vater. J. I.5.697

Velitchkova. M. II.13.74I

Venturoli, G. III.2.193

Vermals. W.F.J. IV.12.805

Verméglio. A. II. 12.653

Vernotte. C. II.1.133

Viale, A.M. III.1.79; III.5.411

Vicira da Silva, J.B. IV.3.169

Vicrling. E. IV.2.14.3

Vigenschow. H. III.2.229)

Viil. J. III.4.293

Vincett, P. I.2.221

Virgili. M. III.2.193

Vitseva, O.I. III.1.21

Vivekanandan. M. III.3.257

Völker. M. 1.5.519.545: 111.1.99

von Schütz. J.U. I.4.427

Vos. M. 1.1.1.3 I.1.29)

Vredenbers. W.J. II.5.3\$3: II.12.613.617,621

Wachtrcitl. J. I.1.87: II.8.5(15)

Wacker. T. I. 4.383

Waggoner, C.M. I.5.685

Wagner. R. III.2.157; III.7.531

Walczak. C. I.2.293

Walker. ('J. IV.8.469, 483

Walker, D.A. III.4.3()9. 313

Wallsgrove. R.M. III.9.629

Walmsley. J. IV.8.487

Wang. D.C. II.6.405

Wang, P. III.5.423

Wang. W. -y. IV.8.423

Wang. Z. II. 7.493

Warden. J.T. 1.2.289. 293

Warncke, K. I.2.225 
Watanabe, A. IV.10.629

Watanabe, T. I.3.303: 1.5.701

Webb, M.S. II.1.197

Webb. R. II.5.375

Webb, S.P. I.1.83. 135

Webber, A.N. I.5.717: II.3.285; III.7.523

Wegmann, B. IV.8.423

Wei. J.M. III.1.37. 10)3

Weinstein, J.D. IV.8.431, 435

Weis, E. II.11.553

Weisbeck, P. IV.9.569

Weiss. W. 1.5.541

Welte. W. I.4.383

Werneke, J.M. III.5.371. 379

Wessler. A.N. IV.8.575

Westerhuis, W.H.J. I.1.29

Whitaker, R.A. IV.12.797

White, M.J. II.1.193; IV.9.577

Whitelegge, J.P. II.15.8()9

Whitmarsh. J. II.2.233, 237; II.7.441, 445

Widell, A. II.1.225, 229

Widger, W. R. II.1.173: II.7.481: III.6.467

Wild. A. II.5.363

Wildner. G.F. III.11.787

Willey. D.L. IV.10.617. 625

Williams. C. IV.10.753

Williams, J.C. III.11.675

Williams, J.G.K. IV.12.8(5), 8(19. 813

Williams, J.P. IV.2.119. 123. 127

Williams, M.L. III.10.705. 7(09

Williams, W.P. II.1.201: IV.1.35

Willms. I. II.7.46.5

Wintermans, J.F.G.M. II.1.205. 209

Wissenbach, M. IV.8.491

Witt. H.T. I.5.523, 537

Wittmershaus, B.P. I.1.75

Wolak. A. II.11.569

Wolf. H.C. I. 4.427

Wollenweber. A. I.3.329

Wollmann. F.A. II.4.325, 329; IV.10.655

Wolosiuk. R.A. III.6.4.59

Wong. J.H. III.6.487

Wong. S.C. IV.5.241

Woodrow, I.E. III.4.345; IV.5.221. 225

Woodrow, L. III.9.645, 653

Wraight. C.A. II.6.387, 397, 401
Wu, B.W. 1.5.605

Wydrzynski. T. I.2.285

Wynn. M. IV.11.745

Yachandra. V.K. I.2.249; I.5.557, 561. 565

Yamazaki. I. I.1.91

Yamazaki. T. l.1.91

Yamamoto. Y. 1.5.593

Yat-nan. X. II.12.657

Yciltes. T.O. I.4.375

Yec. B.C. III.2.241. 249; 111.6.487

Yocum, C.F. I.5.463, 681.685. 689

Yokota. A. III.9.577

You. J.-L. 1.3.345, 349

Young. A.T. II.5.359: III.9.665

Young. D.A. IV.11.699

Yu. C.-A. 1.2.225

Yu, L.M. III.1.107

Yuan. J.G. II.13.729

Yun-ling. D. IV.2.99

Yu-zhu, G. III.9.661

Zabulon. G. II.5.371

Zara. S.J. Il.3.269

Zciger. E. IV.5.273

Zclitch. I. III.9.62I

Zenvirth. D. IV.6.3()I

Zepmeusel. R. I.5.697

Zhang. C. I.4.431

Zhang. Q.D. II.13.729

Zhong. W. III.9.661

Zhou, Q. I.4.395, 411

Zhu. Y.-S. IV.9.519: IV.11.717

Zicgler. K. Il.1.37

Zicgler. P. III.11.80.3

Zicgler. Jöns. A. IV.5.229. 233

Zilinskas. B.A. Il.1.161

Zimanyi, L. II.14.793

Zimmerman. J.L. 1.5.65.3

Ziplel. W. II.II.6()9

Zitkus, P.D. II.4.321

Zonneveld. F.T.M. I.4.4.3.5

Zsako. J. II. $\$ .333$

Zuber. H. II.1.1. 13. 153

Zucchelli, G. II.13.715

Zviman. M. IV.6.289
Bayerische

Staatsbibliothek

München 